\title{
GEOPHYSICAL AND GEOCHEMICAL SIGNATURE OF RARE METAL GRANITES, CENTRAL EASTERN DESERT, EGYPT: IMPLICATIONS FOR TECTONIC ENVIRONMENT
}

\section{IBRAHIM M. GAAFAR AND KHALED G. ALI}

Nuclear Materials Authority

\begin{abstract}
Magnetic survey is usually used to delineate magnetic-structural lineaments, analysetheir relationships to the inherited ductile fabrics and estimate the depth of perturbing body sources, probably granitic intrusions. These were conducted on the total magnetic intensity map reduced to the pole as well as First Vertical Derivative and Euler Deconvolutionmaps to show various aeromagnetic structural lineaments which were interpreted as fault systems.

The early deformational event as(D1) produced sets of NE-SW striking local and regional fractures and faults. The second deformational event (D2) generated mainly NNW-SSE and NW-SE faults and fractures some of which intersected earlier (D1) structures. At the northern and eastern parts of the study area (D1/D2) intersections are observed. The last event (D3)created NNE-SSW set of fractures and faults brought out by splay of dykes and reactivated some (D1 and D2)fractures and faults. The study area is also characterized by a major, $N$-S trending, late-stage dyke system that extends through the area.

In order to estimate source depths from gridded aeromagnetic data, 3-D Euler Deconvolution method was applied. The calculated source depths are in the range of $200 \mathrm{~m}$ to $3500 \mathrm{~m}$. The deepest structures are in the ENE-WSW direction and have depths ranging from about $1100 \mathrm{~m}$ to $3000 \mathrm{~m}$ in the southeastern part of the study area. On the other hand, the network of parallel major structures trending in NNW-SSE direction have a shallow depth of about $700 \mathrm{~m}$.

Rare-metal granites of the central Eastern Desert of Egypt are classified chemically into alkaline to peralkaline and peraluminous granites. They display the typical geochemical characteristics of A-type granites, with high SiO2, Na2O+K2O, Rb, $\mathrm{Zr}, \mathrm{Nb}, \mathrm{Ta}, \mathrm{Sn}$, and $\mathrm{Y}$, and low $\mathrm{CaO}, \mathrm{MgO}$, Baand Sr. The magmatism of the rare metal granites of the central Eastern Desert are related to anorogenic, within-plate, A-type, subvolcanic setting and emplaced in the extensional tectonic regimealong to the inherited ductile fabrics.
\end{abstract}

Keywords: Rare-metal granites, Magnetic survey, Structural lineaments

\section{INTRODUCTION}

Many exploration activities, carried out in the Central Eastern Desert (CED) of Egypt,led to confirm the metallogenetic importance of younger granites. Some of these granites present albite enrichment, which attracted an increased economic interest, due to their association with high concentrations of rare metals, such as:Sn, $\mathrm{U}, \mathrm{Nb}, \mathrm{Ta}, \mathrm{Y}, \mathrm{Zr}$, and REE (Abd-Elmeguid et al., 2003).

There are 15 albitegranitoid plutons in the Eastern Desert (ED) of Egypt, which were $\mathrm{Sn}-\mathrm{W}-\mathrm{Nb}-\mathrm{Ta}$ enriched (rare-metal granites "RMG"). These were first described in some detail by Sabetet al., (1976) and others. They have the following general features: small size $(<1$ to $3 \mathrm{~km} 2$ in outcrop), often part of larger granitic massifs; with domal (Nuweibi, Muelha, Zabara, Qash Amir), lensoid (HumrWaggat, Ineigi, Um Naggat) or stock-like (Igla, Abu-Dabab shapes). Depending on geology and composition of the host rocks, rare metal deposits which related to enriched albite granites can be divided into four different types (Fetherston2004): 1. Peraluminous rare-element granitic pegmatites, mineralized with $\mathrm{Ta}, \mathrm{Li}, \mathrm{Cs},(\mathrm{Be}, \mathrm{Sn}$, and Nb). 2. Peraluminous rare-metal granites, also known as $\mathrm{Li}-$ mica albite granites, Li-F granites, or apogranites, mineralized with $\mathrm{Ta}$ and $\mathrm{Sn},(\mathrm{Be}, \mathrm{Li}$, and $\mathrm{Nb})$. 3. Peralkaline granites and quartz syenites mineralized with $\mathrm{Zr}$, rare earth elements (REE), and $\mathrm{Nb},(\mathrm{Ta}, \mathrm{Sn}, \mathrm{U}$, and Th). 4. Carbonatites and nephelinesyenites mineralized with $\mathrm{Nb}$, REE, $\mathrm{P}$, and $\mathrm{Zr}$, (Ta).

A metasomatic origin was proposed for the origin of albite-rich granites (Beus et al., 1962). Therefore, they named these plutons asapogranites and concluded that the rare-metal enrichment and other compositional peculiarities were post-magmatic. These viewpoints were challenged by the discovery of volcanic and subvolcanic equivalents of apogranites (Cuney et al., 
1992). The studies of these rocks, along with experimental results on the granitic system with addition of fluorine, boron and lithium (London, 1987) have led many recent workers to consider the unusual compositional features of albite granites and rare-metal pegmatites to be magmatic (Cerny 1991).

This work aims to determine geophysical and geochemical signatures of rare-metal granites in the CEDof Egypt and their tectonic setting implications, which plays an important role in granitic emplacement and albitizationof rare-metal mineralization. Aeromagnetic method, being a faster economical and versatile geophysical tool, may help reveal both large and small-scale features, including differences in basement rocktypes, magmatic intrusions, basement surface and fault structures (Vasanthi et al., 2006).

\section{GEOLOGICAL SETTING}

\section{Geological Environment of Rare Metal Granites}

In the CED of Egypt, Abu Dabab,Nuweibiand Um Naggat, other rare metal granites were emplaced in juvenile Neo-Proterozoic (Fig. 1). They are made up of ophiolitic mélange, synorogenicmetagabbro-diorite complexes and granitoids, late to post-orogenicgranitoid intrusions, as well as post-accretionaryvolcanics and molasses-type sedimentary rocks (Helba et al., 1997;Ali, 2003).

\section{Abu Dababalbite granite}

Abu Dabab granite takes an ellipsoidal shape, except its north-western part, whichexists a narrow off-shoot, about $150 \mathrm{~m}$ in length. It is elongated in an E-W direction, with a maximum length of about $400 \mathrm{~m}$ (Fig. 2). The albite granite of Abu Dabab is leucocratic, holocrystalline, white grey to greenish blue with manganese oxides spots and dendrites. It is mostly fine- to medium-grained and occasionally possesses a porphyritic texture. The characteristic alteration processes in the Abu Dabab granite are greisenisation, microclinisation, silicification and albitisation.

Ta-Nb-Sn mineralisation at Abu Dabab is represented by disseminated cassiterite and niobio-tantalite, hosted in a stock of albite granite. No significant disseminated mineralisation is present in the country rocks surrounding the intrusive mass, therefore, the ore deposit limits correspond to the limits of the granitic body (Sabet et al., 1976).

\section{Nuweibialbite granite}

Nuweibialbite granite is divided into eastern fine-grained albite granite and western medium-grained albite granite parts, by a strike-slip fault along WadiNuweibi (Fig. 3). The contact between Nuweibi granite and country rocks is locally marked by a stockscheider consisting of feldspar-quartz pegmatite and quartz cap (Renno, et al., 1993; Ali, 2003). Tin mineralisation was first discovered at Nuweibi in 1944 but until 1970, tantalum was also recognised. The deposit was the subject of detailed exploration by the same joint Soviet-Egyptian team that explored Abu Dabab. The Nuweibi mineralisation is hosted by albite granite intrusive, within a sequence of serpentinites, gabbros, older granites and dykes of varying compositions. The albite granite that hosts the mineralisation is comprised of three main facies, an upper, middle and lower, each separated by a transition zone. The eastern part of Nuweibi granite has higher modal albite contents and lower $\mathrm{Nb} / \mathrm{Ta}$ ratios $(\sim 0.4$, Helba et al.,1997) and contains indicated and inferred resources of $98 \mathrm{Mt}$ of ore at $146 \mathrm{~g} / \mathrm{t} \mathrm{Ta2O5}$ (Gippsland Ltd, 2007). In addition, microlite, (REE-rich) zircon, monazite, xenotime-(Yb), thorianite, REE fluoro-carbonates and fluorite were identified as accessory phases in mineralised granites from Abu Dabab and Nuweibi (Frank et al., 2015).

\section{Um Naggatalbitegranite}

Um Naggat granites (Fig. 4) represent a concentrically zoned, elliptical-shaped (with an ENE-WSW large axis), $13 \times 7.5 \mathrm{~km}$, granitic body is composed of: 1) a central biotitemonzogranite with allanite and titanite, 2) an outer alkaline to peralkaline granites rim with hypersolvus textures, with biotite, allanite, cassiterite and fluorite. The northern rim of the granite is albitized (40 to $240 \mathrm{~m}$ width and $8 \mathrm{~km}$ long). Alterationsare developed along a NW-trending structure andkaolinzation, greisenization alterations and yellow to violet fluorite veins are recorded (Gaafar, 2015). Pegmatite lenses (1.0 x 
$0.3 \mathrm{~m}$ ) are characterized by garnet, fluorite and $\mathrm{Nb}$-Ta mineralization occur at the northern margin. The high Nb (104 to $672 \mathrm{ppm}$ ), Zr (223 to 2022ppm) and Y (35 to 180ppm) contents of the two granites indicate an alkaline to peralkalinefeatures for both of them (Gaafar, 2015).

\section{AIRBORNE MAGNETIC DATA}

Magnetic anomalies in the Earth's magnetic field are caused by magnetic minerals in the rocks, and maps of these anomalies can be interpreted in terms of geology (Silva et al., 2003). The main goal for the use of the aeromagnetic data is to delineate geology and structures which normally serve as conduits for hydrothermal fluid deposition. The concentration of magnetic minerals or their excessive destruction by hydrothermal alterations, especially along tectonic structures enhances the use of this method for the detection of geological structures (Plumlee et al., 1992). In order to locate the observed magnetic anomalies directly over the magnetic source bodies, the total aeromagnetic-intensity grid was transformed into reduction to the pole (RTP)magnetic-intensity grid map (Murphy, 2007) using the 2D-FFT filter. This map of RTP magnetic data (Fig.5) sharpens the contacts between the magnetic high and low patterns as well as anomalously high magnetic susceptible zones probably coming from deeper sources. Analytical maps are useful as a type of reduction to pole when applied to magnetic data collected from low magnetic latitudes, such as the study area. The analytic signal amplitude is independent of the direction of magnetization of the source and is related to the amplitude of magnetization (Roest and Pilkington, 1993).

Geological concepts are applied for targeting structural settings favourable for rare-metal deposits, using detailed magnetic images. They are also used to locate subsurface prospectives of typical outcrops. The identification of these favourable structural settings, led to the increased use of aeromagnetic data in rare metal deposit exploration.

This suggests that the anomalies on the total magnetic intensity map reduced to the northpole (RTP), anomalies are strongly influenced by regional tectonics. The reduction to the pole (RTP) operation transforms the observed magnetic anomaly into the anomaly that would have been measured if the magnetization and ambient field were both vertical. This puts the limits of the magnetic anomalies directly over their sources, like gravity anomalies, thus making magnetic interpretation easier and more reliable.

The map of RTP magnetic data (Fig. 5) shows the observed magnetic anomalies directly over the magnetic source bodies and sharpens the contacts between the magnetic high and low patterns as well as anomalously high magnetic susceptible zones probably coming from deeper sources. The sharp contacts between granitic outcrops with metavolcanics on the eastern and northern parts of the geologic map are clearly obvious on the various magnetic maps. They also confirm the great agreement of the magnetic intensity data with surface geological structures, which indicate their extensions in depth. As can be seen, the biotite granite shows values of the magnetic intensity higher than those of the albite granite, which may be due to increase of magnetic mineral content in the former than that in the later. Qualitatively, the RTP map (Fig. 5) shows the magnetic field amplitudes, reach more than 43800 nT.These are relatively high compared with their spatial distribution which are associated with the northeast part. The map shows variations in the magnetic intensity, indicating variations in either lithology or basement topography. Therefore, the main sources of magnetic anomalies are expected to depend on the basement setting and its magnetic properties. The RTP aeromagnetic map of the study area was obtained in an attempt to delineate the subsurface structures (Fig.5). The aeromagnetic anomalies range from 41900 to $43850 \mathrm{nT}$ and are characterized by both low and high frequencies. The map reveals that the positive magnetic anomalies have a general NE-SW and NW-SE directions, which represent the main characteristic structural directions of the Eastern Desert of Egypt.

Figure (6) is a representation of the delineated interpreted magnetic structural lineaments, as deduced from the RTP magnetic map. This interpreted structural map gives an idea about the depositional time-sequence of formation of the 
lithological units and some geological structures in the study area. The interpreted magnetic structural map (Fig. 6) reveals enhanced structural features that include faults, shears, fault intersections and fracture systems that mainly trend in four directions NW-, NNW- NE- and ENE. This is quite obvious, where there are a large number of magnetic markers striking perpendicular to these structures. The most important and perhaps the youngest trends of these structures extend in the NW- and NNW-directions because they are characterized by their long lengths of extensions and cutting most of the rock units and the remaining two structures (NE- and ENE) of the studied area. Consequently, the oldest phase of structural lineaments extends in the ENE-direction that dissects and displaces, mostly with left lateral movement, the youngest structures.

To emphasize the effects of geological contacts, critical for the structural framework of the study area, data processing involved accurate enhancement of the short-wavelength and linear features. In that regard, the aeromagnetic data were first re-gridded with a grid-cell spacing of $250 \mathrm{~m}$ and then subjected to regional/ residual separation to isolate short-wavelength signals which are more suitable for high-resolution mapping of shallow magnetic boundaries. The regional-residual separation of anomalies was applied to the RTP aeromagnetic map of the study area. The Geosoft package software (V.6.3) was used for analysis of the data. Filtering assisted in the discrimination between shallow and deep-seated sources of aeromagnetic anomalies and produced the regional and residual magnetic-component maps (Figs. 7\&8). The high magnetic contrast along the contacts of acidic and basic rocks mostly reflects clearly sharp contacts, as shown on the regional magnetic-component map (Fig. 7). The elongated stretches of low magnetic values generally correspondto granitic rocks. Meanwhile, the broad and high magnetic patterns, seen at the eastern and northeastern parts of the study area, generally represent metavolcanics.

Since the magnetic intensities of older granite decrease sharply along the centre of the study area, therefore, the lowest magnetic values may reflect deep-seated sources of granitic magma, which are elongated from east to west in the central part of the study area. The oval-shaped low magnetic anomaly, that is associated with albite granite, indicates that it is deep-seated, which was resulted from highly-differented patch of albite granite. The residual magnetic-component map (Fig. 8) helped to attenuate broad, more regional anomalies and enhance local, more subtle magnetic responses, because of their sensitivity to shallow magnetic source bodies and contacts. It also assisted to draw and deduce subtle extensions of various structures enhanced by other filtered grids. The residual aeromagneticcomponent image map (Fig. 8) indicates that geological units were fractured and faulted by different tectonic regimes. The granitic plutons are more tectonically disturbed, i.e., increasing rock permeability, thus, possess the potential to host hydrothermal fluids.

Some faults were not clearly noticed on the regional-component areomagnetic map (Fig. 7), but well exposed on the residual one (Fig. 8). Three high anomalous zones, trending in the NE-SW direction, which are associated with metavolcanics, are observed on this image.This configuration of positive anomalies may be attributed to relatively deep-seated, low-relief basement structures.

To delineatethe subsurface structures of the study area, two approaches were followed. These approaches are the first vertical derivative (FVD) method to delineate linear structures and the Euler deconvolution to constrain depths of perturbing body sources. The results of the two methods, with available geological information were used to help in understanding subsurface structures of the study area. Derivatives tend to sharpen the edges of anomalies and enhance shallow features. The FVD map (Fig. 9) is much more responsive to local influences than to broad or regional effects and therefore tends to give sharper image than the aeromagnetic field intensity map. The enhancement of magnetic anomalies associated with faults and other structural discontinuities were achieved by the application of FVD to the residual map (Fig. 9) (Dobrin and Savit, 1988; Telford et al., 1990). 


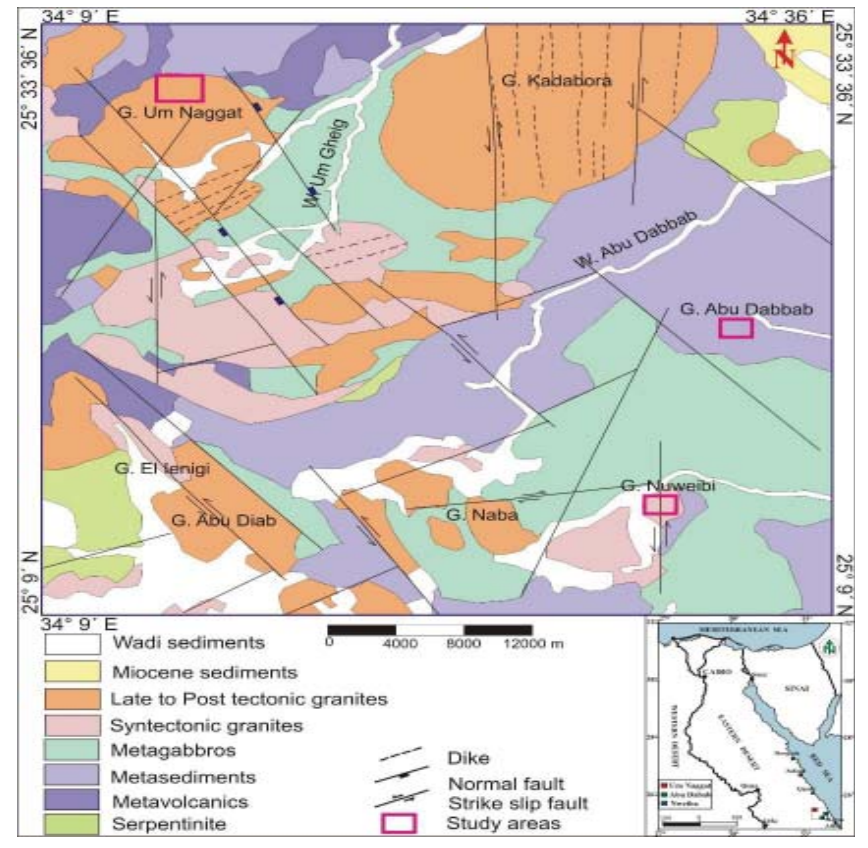

Fig. (1) Geological map of rare metal areas, CED, Egypt and their locations (modified from EGSEMA, 1992).
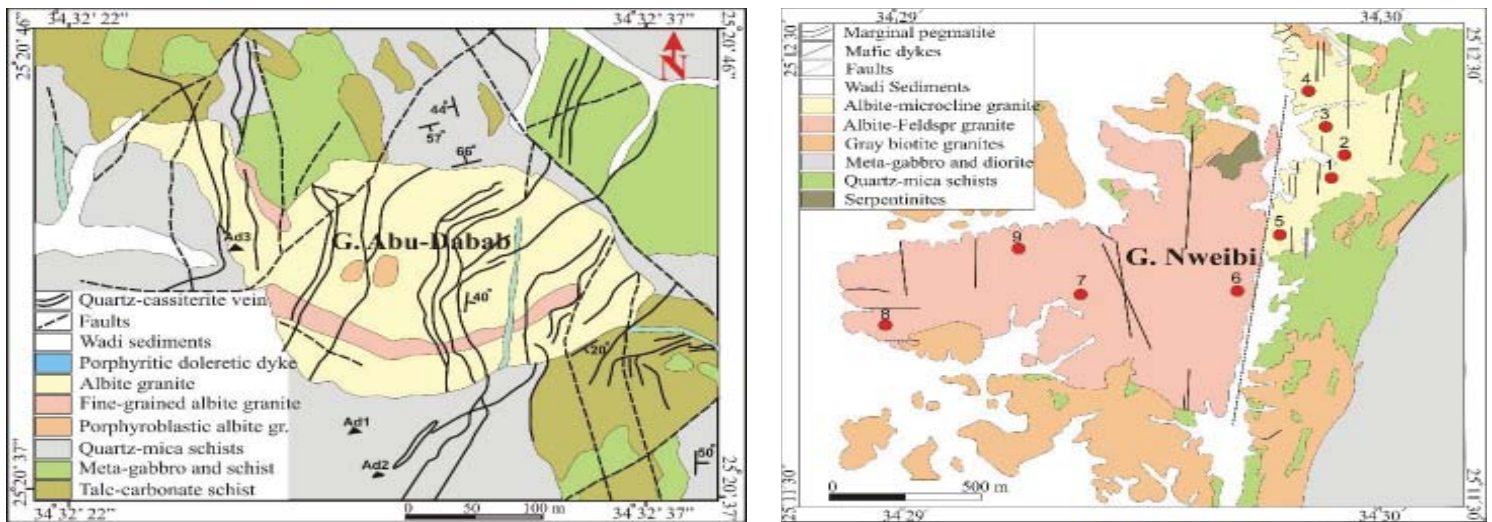

Fig. (2): Geologic map of Abu Dabab area, CED, Egypt (modified from Sabet et al., 1976), and sample location.

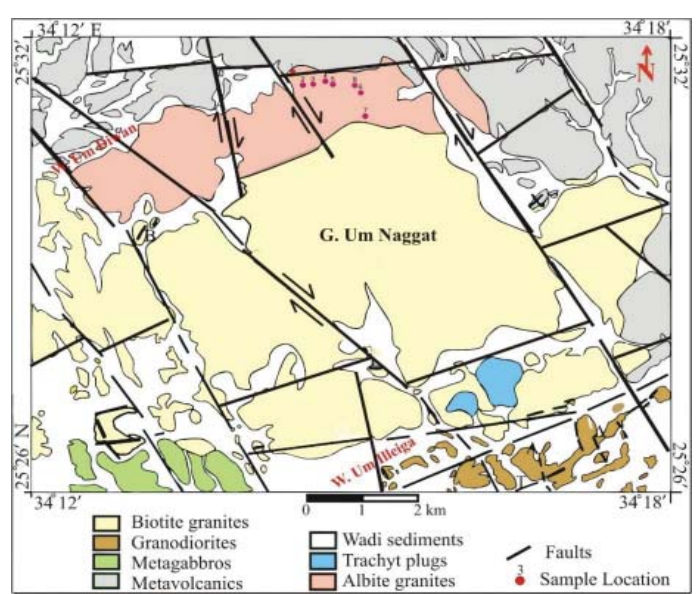

Fig. (4): Geologic map of Um Naggat area, CED,

Egypt (modified after Greiling et al., 1988).

Fig. (3): Geologic map of Nuweibi area, CED, Egypt (Ali, 2003), and sample location.

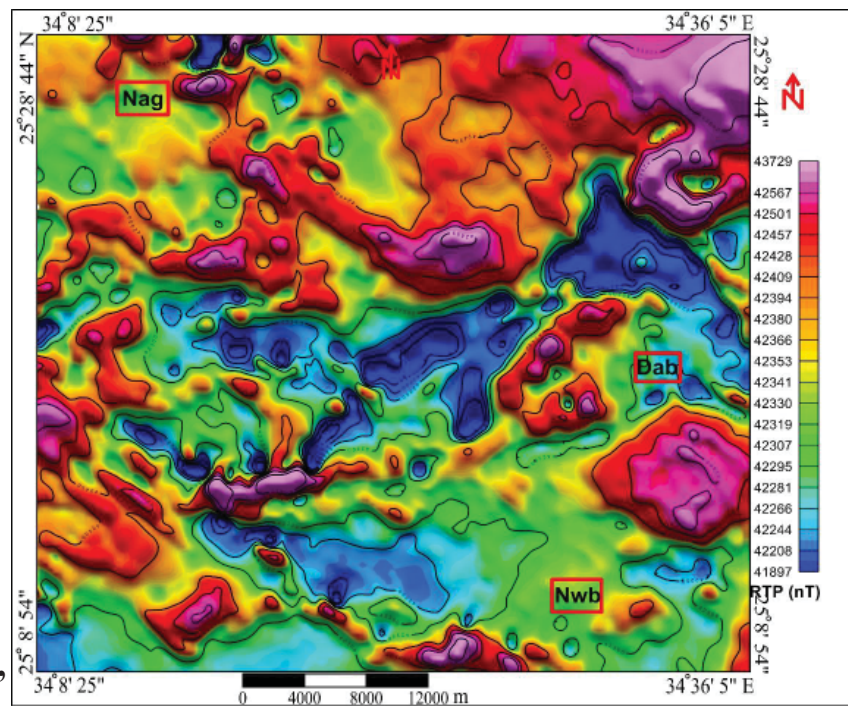

Fig. (5) Total magnetic intensity colour-shaded map reduced to the north magnetic pole (RTP) of the three rare metal granites areas, Central Eastern Desert, Egypt (Aero Service, 1984). 
The FVD aeromagneticstructural lineament map shows the long regional trends which control the subsurface structures beneath the studied area(Fig. 10). In this study, ENE-WSW, WNWESE and E-W are the dominant trends affecting the study area. The relationships among these trends suggest that the area was subjected to more than a single tectonic event.Taking into account the geological setting of the study area characterized by the presence of faults, the general abundance of structural lineaments observed in this part of the area could be related to faulting associated with the concurrence of deep-seated basement structures.

The structures of the study area is character-

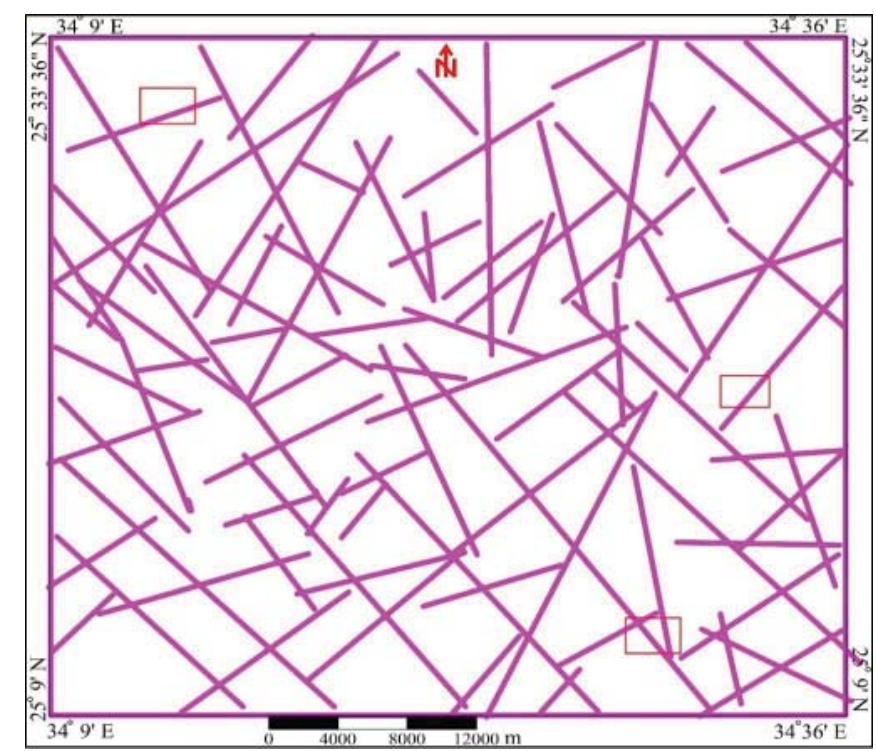

ized by the presence of WNW-ESE and NENW trending ones that correlate well with the trends of aeromagnetic lineaments, identified on the synthetic lineaments map. The study area is dominated by a series of NE trending shears, which are interpreted as high angle fault structures formed during regional NW-SE compression. A higher degree of shearing and faulting at the contact zone of the meta-sediments and metavolcanics, have caused shifting of the dykes towards the NE direction. Figure (5) recorded low magnetic anomalies due to the increase in rock permeability (intense faulting and shearing, thus, the ability to host hydrothermal fluids).

The objective of the 3D Euler deconvolu-

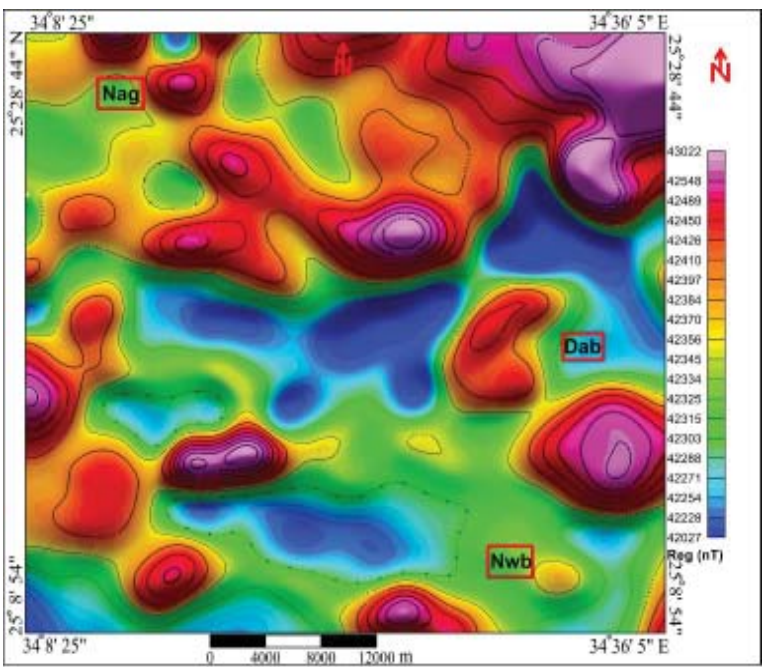

Fig. (7) Regional component of the RTP colour- Fi shaded map of the three rare metal granites areas, Central Eastern Desert, Egypt.

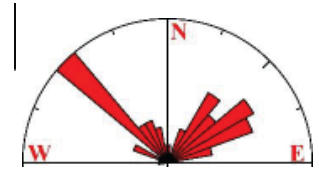

Fig. (6) Lineaments as deduced from the RTP aeromagnetic map with their rose diagram of the three rare metal granites areas, Central Eastern Desert, Egypt

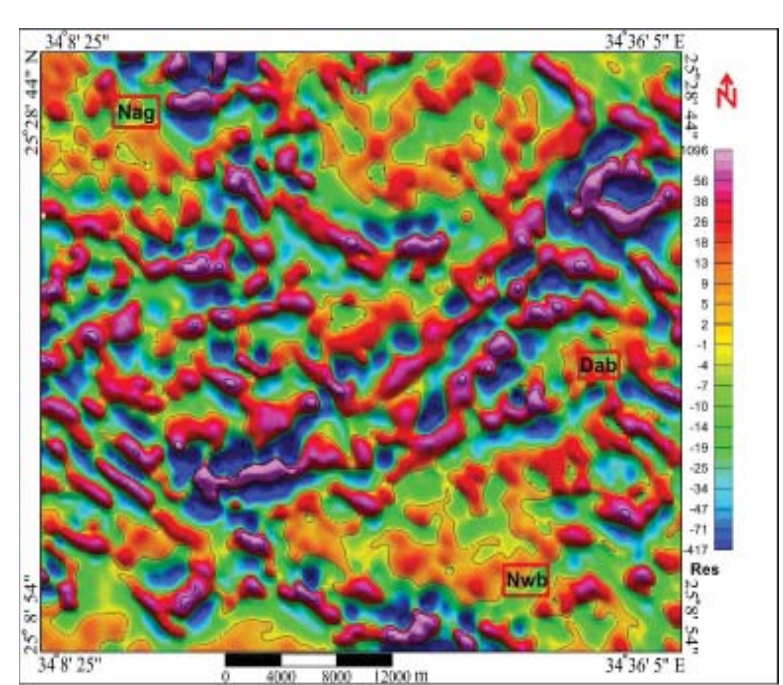

ig. (8) Residual component of the RTP colour-shaded map of the three rare metal granites areas, Central Eastern Desert, Egypt 
tion process is to determine the shapes and corresponding depth estimates of geologic sources of the magnetic anomalies. The way to reduce the instability and decrease the non-uniqueness of the solution is to integrate geological and geophysical constraints into cluster depth maps of dyke structural index (Fig. 11)contact structural index (Fig. 12).
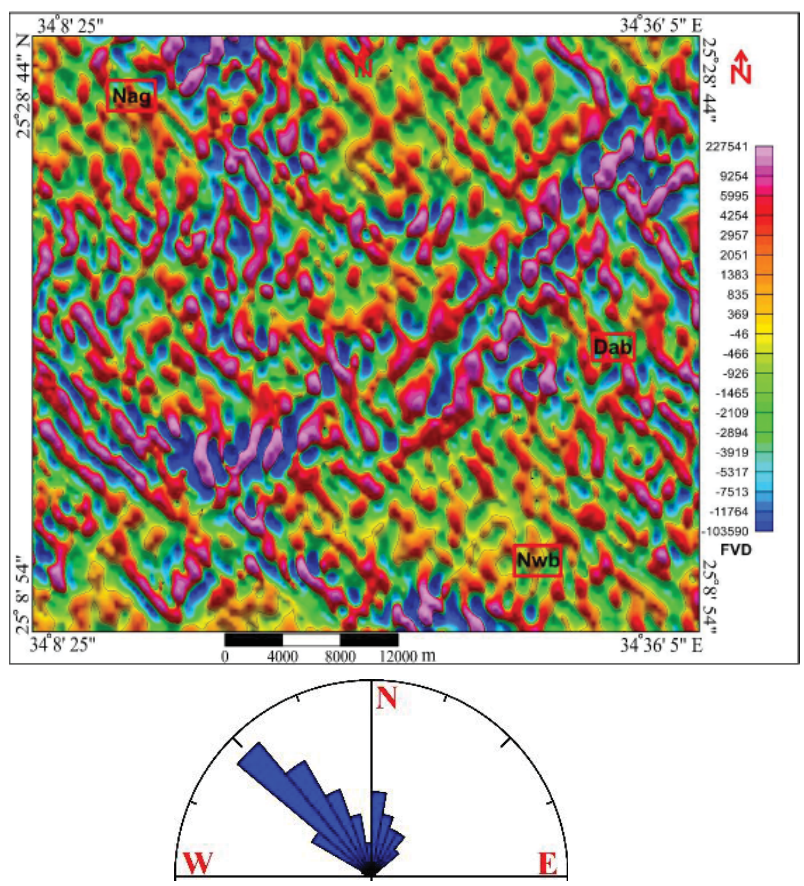

Fig. (9) First Vertical Derivative (FVD) of residual aeromagnetic map of the three rare metal granites areas, Central Eastern Desert, Egypt.

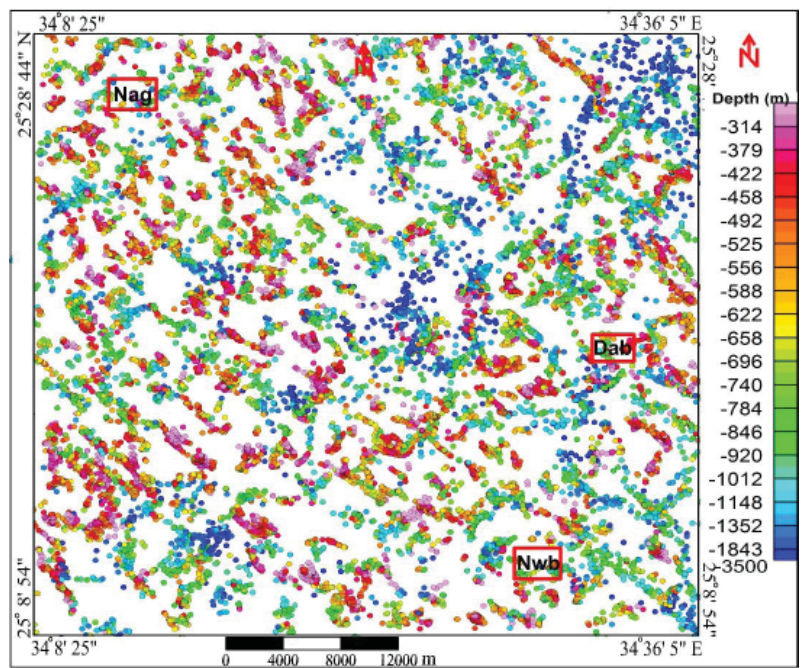

Fig. (11) Euler Deconvolution (SI=1, dyke) map of RTP Fig. (12) Euler Deconvolution (SI=0, contact) map aeromagnetic map of the three rare metal granites areas, Central Eastern Desert, Egypt.
Geophysical constraining is focused mainly on direct interpretation of the magnetic field by Euler deconvolution. The advantage of this method of magnetic data enhancement is that its amplitude function is always positive and does not need any assumption of the direction of body magnetization (Jeng et al., 2003). The maxima of the analytic signal can be used to detect the

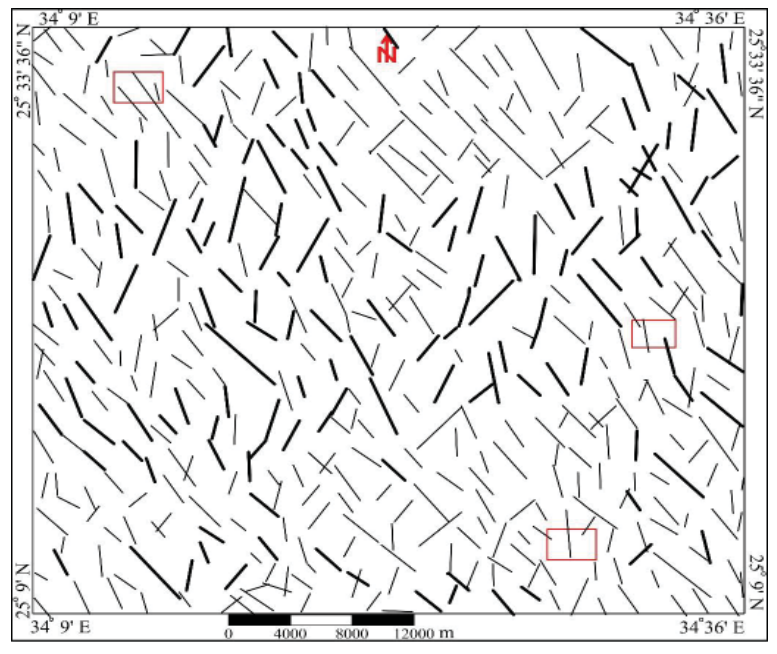

Fig. (10) Lineaments deduced from the FVD aeromagnetic map and their rose diagram of the three rare metal granites areas, Central Eastern Desert, Egypt.

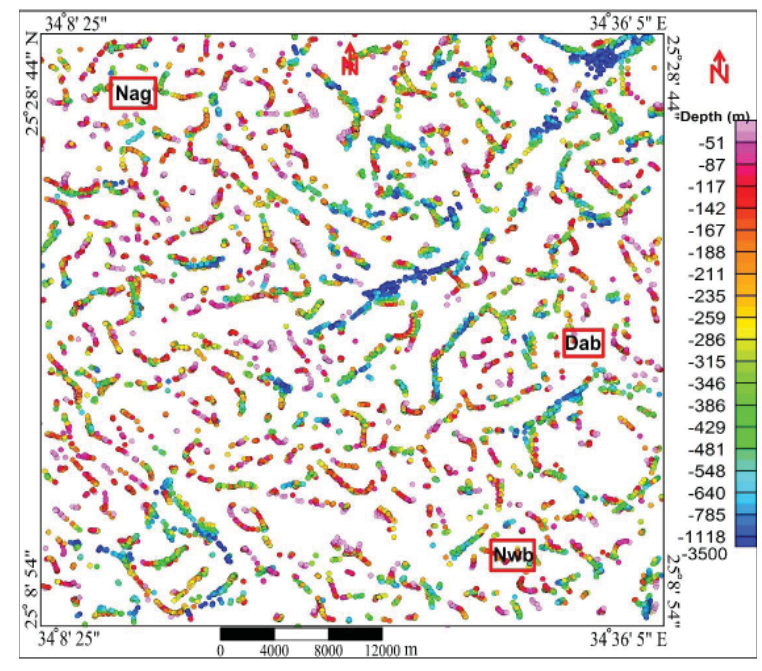
of RTP aeromagnetic map of the three rare metal granites areas, Central Eastern Desert, Egypt. 
structures responsible for the observed magnetic anomalies over the studied area.

Depth estimation by Euler deconvolution technique was used for delineating geologic contacts. This technique provides automatic estimates of source location and depth. Therefore, Euler deconvolution is both a boundary finder and depth estimation method. It is commonly employed in magnetic interpretation, because it requires only a little prior knowledge about the magnetic source geometry, and more importantly, requires no information about the magnetization vector (Thompson, 1982; Reid et al., 1990). The most critical parameter in the Euler deconvolution is the structural index, $\mathrm{N}$ (Thompson, 1982). Therefore, by changing $\mathrm{N}$, the geometry and depth of the magnetic sources can be estimated. For magnetic data, physically plausible $\mathrm{N}$ values range from 0 to 3 .

Several structural index values were assigned for a structural index of $\mathrm{N}=1.0$, the extensions of linear clustering of Euler solutions gave colored points similar to the main trends of the two previous methods. In addition, the Euler solution map reveals new deep contacts, which represent accurate-style trends in the southeast part of the study area. The Euler plot (Fig. 12) clearly defines the solution for depths that range from 200 $\mathrm{m}$ to $3500 \mathrm{~m}$.

Most of the Euler solutions in the central part of the study area show rather shallow depths of about $1100 \mathrm{~m}$ for the possible causative sources. The depths in the eastern part of the study area are not uniform. In itsnortheastern part, the solutions are situated at shallow depths and in the southeastern part the solutions are situated at deep depth of about 1500 to $3000 \mathrm{~m}$. In the northwestern part of the study area, Euler plots also show non-uniform depth distribution from shallow to deep depths.

\section{GEOCHEMICAL ANALYSIS}

\section{Analytical Methods}

Twenty four representative samples were selected from the three different granitic areas (Tables1 and 2). Samples were crushed and powdered using agate mortar to avoid trace elements contamination and then prepared for com- plete chemical analysis by fusion with $\mathrm{LiBO} 2$ and $\mathrm{HNO} 3$ dissolution in the laboratory of Henri Poincaree University, Nancy, France. Major elements were analyzed using an Atomic Emission Spectrometer (AES) coupled with Inductively Plasma (IP) source (Govindarajuet.al., 1976). The analyses of trace elements were analyzed by ICP-MS. Quality control of the analyses was made using international geostandards.

\section{Magmatic Evolution and Tectonic Setting}

Rare metal granites are low in $\mathrm{MgO}, \mathrm{Fe} 2 \mathrm{O} 3$, $\mathrm{CaO}$ andSr and high in $\mathrm{SiO} 2, \mathrm{Na} 2 \mathrm{O}, \mathrm{K} 2 \mathrm{O}, \mathrm{Nb}$, $\mathrm{Ta}, \mathrm{Th}, \mathrm{Sn}, \mathrm{Zr}$, and Y.Debon and Le Fort (1983) proposed a variation diagram depending on millications distributions. They used alumina index $(\mathrm{A})=[\mathrm{Al}-(\mathrm{K}+\mathrm{Na}+\mathrm{Ca})]$, basic index $(\mathrm{B})$ $=[\mathrm{Fe}+\mathrm{Mg}+\mathrm{Ti}]$ and characteristic mineral diagrams for determination of magmatic evolution (Fig. 13). The (A) index is used as indicator to discriminate between peraluminous and metaluminous magma. The studied samples plot in peraluminous domain and Um Naggat granite is less differentiated than Nuweibi and Abu Dabab granites.Rickwood (1989) used the K2O$\mathrm{SiO} 2$ discrimination diagram to differentiate between shoshonite series, high-K calc-alkaline series, medium-K calc-alkaline series and low$\mathrm{K}$ tholeiite(Fig. 14). The studied granite samples plot in the high K-calc alkaline series field. Two samples form Abu Dabab granite plot in the medium K-calc alkaline series field due to albite rich.

According to Maniar and Piccoli (1989),granitoid tectonic classification scheme is based on major oxide (SiO2vs Al2O3 diagram (Fig. 15) Um Naggate, Abu Dabab and Nuweibi granites plot are located in the field of (POG).

Eby (1990) stated that $\mathrm{Y} / \mathrm{Nb}$ ratio can be used as a discrimination index to differentiate between suites with $\mathrm{Y} / \mathrm{Nb}$ ratio $<1.2$ (A-type), which are derived from sources chemically similar to those of oceanic island basalts. Meanwhile, suites with $\mathrm{Y} / \mathrm{Nb}$ ratio $>1.2$ are derived from sources chemically similar to island-arc or continental margin basalts. Figure (16) shows that magmas are emplaced in post-collisional or within plate settings, i.e., an extensional environment and may be produced by the melting of a lithospheric 


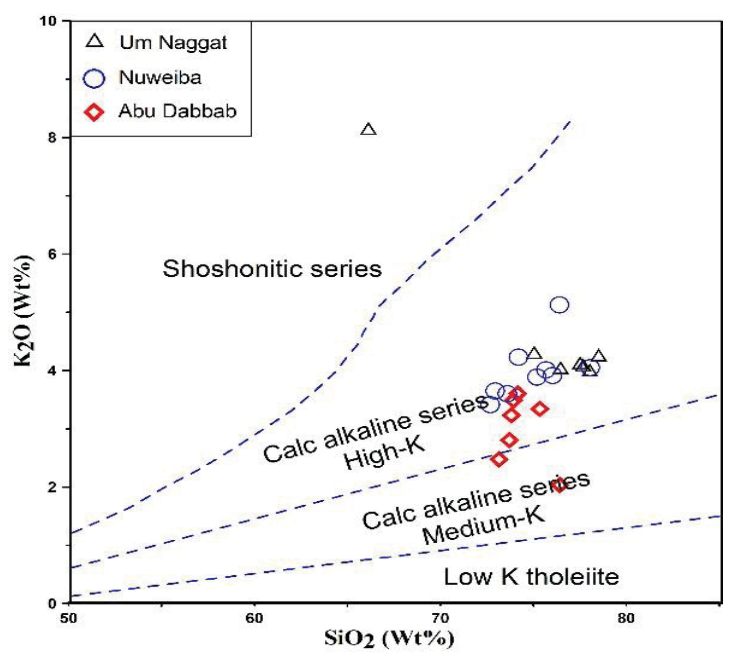

Fig. (13): A-B characteristic minerals of the three studied younger granites (Debon and Le Fort, 1983).

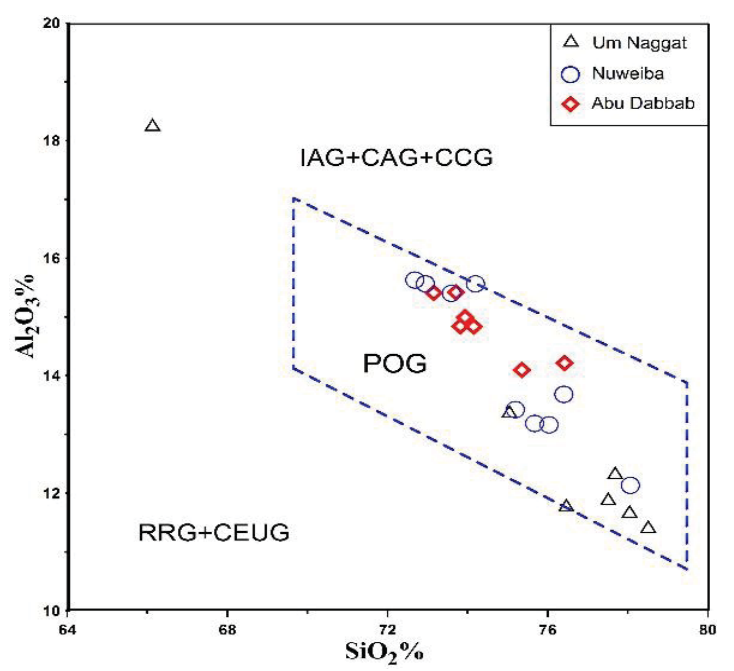

Fig.(15): Al2O3 - SiO2 binary diagram of the studied younger granites after (Maniar and Piccoli, 1989)

source from which a previous melt had been extracted or by differentiation of a basalt magma. This is a very different definition from that of I-and S-type granitoidsbecause it includes both tectonic setting and chemical characteristics of the magmas. They seem to be resulted mainly from partial melting of $\mathrm{F}$ and/or $\mathrm{Cl}$ enriched dry, granulitic residue remaining in the lower crust after extraction of orogenic granite (Whalen et al., 1987). They may be emplaced into tensional environments either at the end of an orogenic cycle (post-orogenic granites), or in continental rift zone (Eby, 1990).

Pearce et al., (1984) used the trace elements

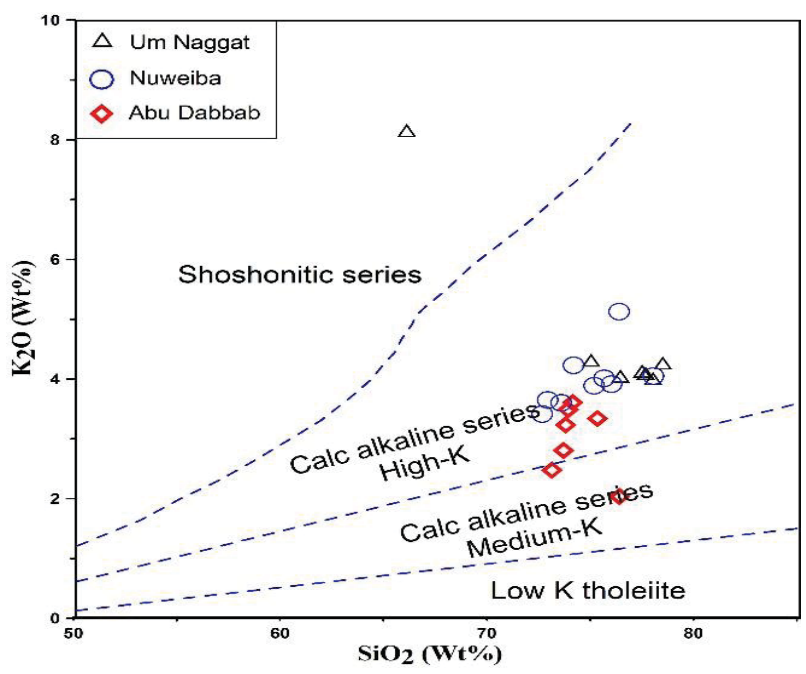

Fig. (14): $\mathrm{SiO2}$ - K2O diagram (Rickwood, 1989) showing the studied granite samples are located in the high-K calc-alkaline series

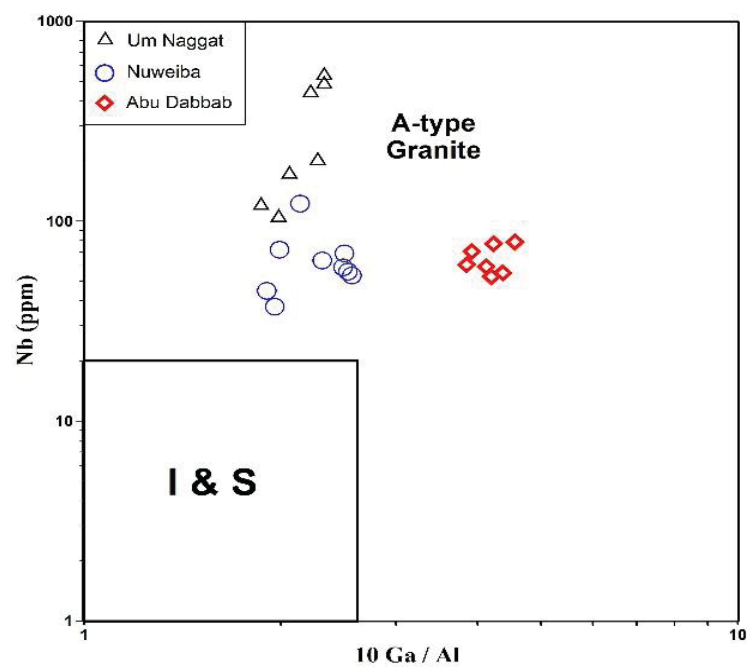

Fig. (16): Ga/AlvsNbA-type granitoid discriminantdiagramafterWhalen et al.,(1987).

to discriminate the tectonic environments of granitic rocks. The studied granites samples plot in the WPG fieldsuggesting their emplacement in a within-plate tectonic setting. (Fig. 17). Figure (18) $(\mathrm{Rb}-(\mathrm{Y}+\mathrm{Ta}))$ shows that studied granite samples plot fall in the within plate granites (WPG) field, but two samples form Abu Dabab granite plot fall in the Ocean Ridge Granites (ORG), due to their Ta high content.

Figure(19) (Y / Nb) vs (Yb / Ta) diagram showing the RMG of CED located in the OIB field were derived from the subcontinental lithosphere or lower crust.

The prominent peralkaline and alkaline nature of the RMG are consistent with their af- 
filiation to extensional environments (Petro et al., 1979). The Y-Ce-Yb ternary diagram (Eby, 1992) showing the RMG of CED located in the A1 field (Fig. 20).Eby (1992) suggested that the
A-type granitoids, based on certain trace element distributions, could be divided into two groups. Granitoids that plot in the A1group were interpreted as differentiates of basalt magma

Table (1): Major oxides (\%) of the Abu Dabab, Nweibi, and Um Naggat granites, C E D, Egypt.

\begin{tabular}{|c|c|c|c|c|c|c|c|c|c|c|c|c|}
\hline & $\mathrm{SiO}_{2}$ & $\mathrm{Al}_{2} \mathrm{O}_{3}$ & $\mathrm{Fe}_{2} \mathrm{O}_{3}$ & MnO & MgO & $\mathrm{CaO}$ & $\mathrm{Na}_{2} \mathrm{O}$ & $\mathrm{K}_{2} \mathrm{O}$ & $\mathrm{Ti}_{2} \mathrm{O}_{3}$ & $\mathbf{P}_{2} \mathrm{O}_{5}$ & IL & Total \\
\hline Dab1 & 73.8 & 14.9 & 0.4 & 0.1 & 0.1 & 0.2 & 6.1 & 3.2 & < L.D. & < L.D. & 0.9 & 100 \\
\hline Dab2 & 75.4 & 14.1 & 0.4 & 0.1 & 0.1 & 0.1 & 5.6 & 3.3 & < L.D. & < L.D. & 0.8 & 100 \\
\hline Dab3 & 74.2 & 14.8 & 0.4 & 0.1 & 0.1 & 0.2 & 5.9 & 3.6 & $<$ L.D. & $<$ L.D. & 0.9 & 100 \\
\hline Dab4 & 73.2 & 15.4 & 0.5 & 0.1 & 0.1 & 0.2 & 6.6 & 2.5 & $<$ L.D. & $<$ L.D. & 1.3 & 100 \\
\hline Dab5 & 76.4 & 14.2 & 0.5 & 0.1 & $<$ L.D. & 0.1 & 6.5 & 2 & $<$ L.D. & $<$ L.D. & 0.7 & 100 \\
\hline Dab6 & 73.9 & 15 & 0.3 & 0.1 & < L.D. & 0.1 & 6.2 & 3.5 & $<$ L.D. & < L.D. & 0.7 & 100 \\
\hline Dab7 & 73.7 & 15.4 & 0.5 & 0.1 & 0.1 & $<$ L.D. & 6.6 & 2.8 & < L.D. & $<$ L.D. & 0.8 & 100 \\
\hline Nwb1 & 72.9 & 15.6 & 0.3 & 0.1 & < L.D. & $<$ L.D. & 6.7 & 3.7 & < L.D. & < L.D. & 0.5 & 100 \\
\hline Nwb2 & 72.7 & 15.6 & 0.4 & 0.1 & < L.D. & $<$ L.D. & 6.9 & 3.4 & < L.D. & < L.D. & 0.5 & 100 \\
\hline Nwb3 & 74.2 & 15.6 & 0.5 & 0.1 & < L.D. & 0.1 & 6.1 & 4.2 & < L.D. & < L.D. & 0.5 & 101 \\
\hline Nwb4 & 76.4 & 13.7 & 0.6 & 0.1 & $<$ L.D. & 0.1 & 4.2 & 5.1 & $<$ L.D. & $<$ L.D. & 0.6 & 101 \\
\hline Nwb5 & 73.6 & 15.4 & 0.3 & 0.1 & $<$ L.D. & 0.1 & 6.5 & 3.6 & $<$ L.D. & $<$ L.D. & 0.5 & 100 \\
\hline Nwb6 & 78.1 & 12.1 & 0.6 & 0.2 & $<$ L.D. & 0.1 & 4.3 & 4.1 & $<$ L.D. & $<$ L.D. & 0.6 & 100 \\
\hline Nwb7 & 75.2 & 13.4 & 0.6 & 0.1 & $<$ L.D. & 0.1 & 5.4 & 3.9 & $<$ L.D. & $<$ L.D. & 0.6 & 99 \\
\hline Nwb8 & 76 & 13.2 & 0.6 & 0.1 & < L.D. & 0.1 & 5.2 & 3.9 & < L.D. & $<$ L.D. & 0.4 & 100 \\
\hline Nwb9 & 75.7 & 13.2 & 0.6 & 0.1 & < L.D. & 0.2 & 5.2 & 4 & $<$ L.D. & $<$ L.D. & 0.6 & 100 \\
\hline Nag1 & 83.7 & 9.8 & 0.6 & $<$ L.D. & 0.1 & 2.1 & 0.2 & 1.8 & < L.D. & < L.D. & 2.6 & 101 \\
\hline Nag2 & 77.7 & 12.3 & 1.2 & $<$ L.D. & < L.D. & 0.1 & 3.9 & 4.1 & < L.D. & < L.D. & 0.9 & 100 \\
\hline Nag3 & 78 & 11.7 & 1.4 & $<$ L.D. & $<$ L.D. & 0.1 & 3.9 & 4 & $<$ L.D. & $<$ L.D. & 0.8 & 100 \\
\hline Nag4 & 75 & 13.4 & 1.4 & $<$ L.D. & $<$ L.D. & 0.1 & 5 & 4.3 & $<$ L.D. & $<$ L.D. & 0.7 & 100 \\
\hline Nag5 & 78.5 & 11.4 & 1.2 & $<$ L.D. & 0.1 & 0.1 & 3.6 & 4.2 & $<$ L.D. & $<$ L.D. & 0.7 & 100 \\
\hline Nag6 & 77.5 & 11.9 & 1.3 & 0.1 & 0.1 & 0.2 & 4 & 4.1 & 0.1 & $<$ L.D. & 0.7 & 100 \\
\hline Nag7 & 76.5 & 11.8 & 1.5 & 0.1 & $<$ L.D. & 0.2 & 4.3 & 4 & 0.1 & $<$ L.D. & 0.6 & 99 \\
\hline Nag8 & 66.1 & 18.2 & 0.6 & $<$ L.D. & 0.1 & 0.1 & 5.3 & 8.1 & $<$ L.D. & $<$ L.D. & 0.6 & 99 \\
\hline
\end{tabular}

Table (2): Some trace elements (ppm) of the Abu Dabab, Nweibi, and Um Naggat granites, C E D, Egypt.

\begin{tabular}{|c|c|c|c|c|c|c|c|c|c|c|c|c|c|c|c|}
\hline Ref & $\mathbf{B a}$ & Hf & Mo & Nb & $\mathbf{P b}$ & $\mathbf{R b}$ & Sn & $\mathrm{Sr}$ & Ta & Th & $\mathbf{U}$ & $\mathbf{W}$ & $Y$ & $\mathbf{Z n}$ & $\mathbf{Z r}$ \\
\hline Dab1 & 12.72 & 17.7 & 0.6 & 70.5 & 15.3 & 516.1 & 731.2 & 20.0 & 164.4 & $\begin{array}{l}10.7 \\
\end{array}$ & 7.0 & 4.5 & 5.2 & 445.9 & 43.4 \\
\hline Dab2 & 4.47 & 22.6 & $<$ L.D. & 59.3 & 14.6 & 631.3 & 932.4 & 11.1 & 177.7 & 6.2 & 7.1 & 4.0 & 4.3 & 464.0 & 44.7 \\
\hline Dab3 & 9.07 & 17.3 & $<$ L.D. & 60.6 & 15.9 & 576.9 & $\begin{array}{l}673.2 \\
\end{array}$ & 15.0 & 145.1 & 11.1 & 6.0 & 5.0 & 4.7 & 506.6 & 42.1 \\
\hline Dab4 & 5.31 & \begin{tabular}{|l|}
46.1 \\
\end{tabular} & $<$ L.D. & \begin{tabular}{|l|}
78.5 \\
\end{tabular} & 12.7 & 503.1 & 1598.0 & 12.8 & 540.3 & 14.2 & 8.5 & 7.6 & 1.5 & 744.9 & 64.9 \\
\hline Dab5 & 9.88 & 21.4 & 0.5 & 52.8 & 14.1 & 375.4 & 4193.0 & 11.1 & 203.3 & 21.7 & 6.8 & 5.2 & 5.6 & 267.9 & 41.3 \\
\hline Dab6 & 11.8 & 33.3 & $<$ L.D. & 77.2 & 12.3 & 573.5 & $\begin{array}{l}765.8 \\
\end{array}$ & 10.9 & 249.1 & 4.9 & 5.3 & 2.1 & 4.3 & 366.3 & 62.0 \\
\hline Dab7 & 6.261 & 52.6 & $<$ L.D. & 55.2 & 12.9 & 506.4 & 2883.0 & 8.4 & 513.2 & 17.0 & 10.0 & 3.2 & 8.3 & 235.2 & 78.8 \\
\hline Nwb1 & 11.03 & 23.2 & 2.6 & 56.0 & 45.3 & 468.9 & 63.3 & 9.0 & 129.2 & 18.5 & 5.4 & 1.7 & 3.5 & 61.6 & 54.2 \\
\hline Nwb2 & 7.133 & 23.2 & 0.8 & 53.5 & 35.7 & 431.4 & 161.7 & 9.8 & 131.8 & 18.2 & 5.4 & 1.3 & 2.6 & 28.1 & 53.4 \\
\hline Nwb3 & 3.718 & 22.3 & 11.7 & 58.8 & $\begin{array}{ll}51.8 \\
\end{array}$ & 530.5 & 44.1 & 5.9 & 171.9 & 19.3 & 6.5 & 1.4 & 3.9 & 103.9 & 65.8 \\
\hline Nwb4 & 8.59 & 10.0 & 9.0 & 63.7 & 56.7 & 553.1 & 39.2 & 6.0 & 99.0 & 23.4 & 5.8 & 1.0 & 3.0 & 83.8 & 39.7 \\
\hline Nwb5 & 13.84 & 22.6 & 1.6 & 68.9 & 48.2 & 503.5 & 34.7 & 6.3 & 99.6 & 16.8 & 5.1 & 0.6 & 3.4 & 48.4 & 57.7 \\
\hline Nwb6 & 3.57 & 23.0 & 0.6 & 122.4 & 39.1 & 603.3 & 154.7 & <L.D. & 54.7 & 23.2 & 3.7 & 0.5 & 2.8 & 357.7 & 91.4 \\
\hline Nwb7 & 6.43 & 22.2 & $<$ L.D. & 72.0 & 52.5 & 499.9 & 121.6 & 7.1 & \begin{tabular}{|l|}
28.9 \\
\end{tabular} & 26.7 & 4.7 & 0.3 & 17.3 & 311.4 & 130.0 \\
\hline Nwb8 & 1.86 & 18.2 & $<$ L.D. & 37.3 & 47.3 & 360.5 & 77.3 & 4.6 & 25.4 & 23.1 & 2.8 & $<$ L.D. & 12.0 & 225.5 & 99.6 \\
\hline Nwb9 & 2.97 & 21.2 & $<$ L.D. & 44.8 & 52.2 & 406.9 & 56.2 & 6.9 & 21.9 & 26.6 & 4.8 & 0.3 & 16.0 & 288.9 & 129.5 \\
\hline Nag1 & 52.13 & 101.8 & 189.5 & 672.1 & 434.1 & 369.1 & 82.9 & 30.4 & 113.4 & 165.8 & 61.6 & 8.3 & 116.6 & 41.6 & 1391.0 \\
\hline Nag2 & 14.3 & 48.5 & 4.5 & 438.9 & 9.4 & 630.5 & 23.8 & 13.0 & 46.2 & 67.3 & 49.4 & 3.8 & 74.8 & 404.9 & 739.5 \\
\hline Nag3 & 13.34 & 109.0 & 4.3 & 536.3 & 10.6 & 780.9 & 38.1 & 8.8 & 59.0 & 68.7 & 50.4 & 5.0 & 98.9 & 244.5 & 2022.0 \\
\hline Nag4 & 6.08 & 28.5 & 1.0 & 201.4 & 17.3 & 778.2 & 52.7 & 6.6 & 28.7 & 45.9 & 23.1 & 2.7 & 35.0 & 276.6 & 403.5 \\
\hline Nag5 & 14.68 & 72.2 & 3.3 & 484.8 & 15.8 & 745.9 & 55.3 & 6.6 & 50.9 & 62.5 & 64.8 & 4.8 & 42.6 & 216.2 & 1196.0 \\
\hline Nag6 & 30.23 & 20.3 & 2.0 & 171.8 & 10.5 & 438.8 & 65.1 & 6.8 & 18.5 & 30.3 & 10.3 & 2.5 & 94.0 & 533.9 & 350.2 \\
\hline Nag7 & 13.27 & 14.9 & 1.7 & 104.4 & 10.7 & 306.6 & 96.4 & 9.8 & 12.7 & 19.5 & 9.0 & 1.5 & 128.8 & 419.0 & 223.7 \\
\hline Nag8 & 21.88 & 22.5 & 1.7 & 120.0 & 17.2 & 1021.0 & 3.6 & 10.2 & \begin{tabular}{|l|}
19.4 \\
\end{tabular} & 22.9 & 7.3 & 1.9 & 180.9 & 77.2 & 297.1 \\
\hline
\end{tabular}




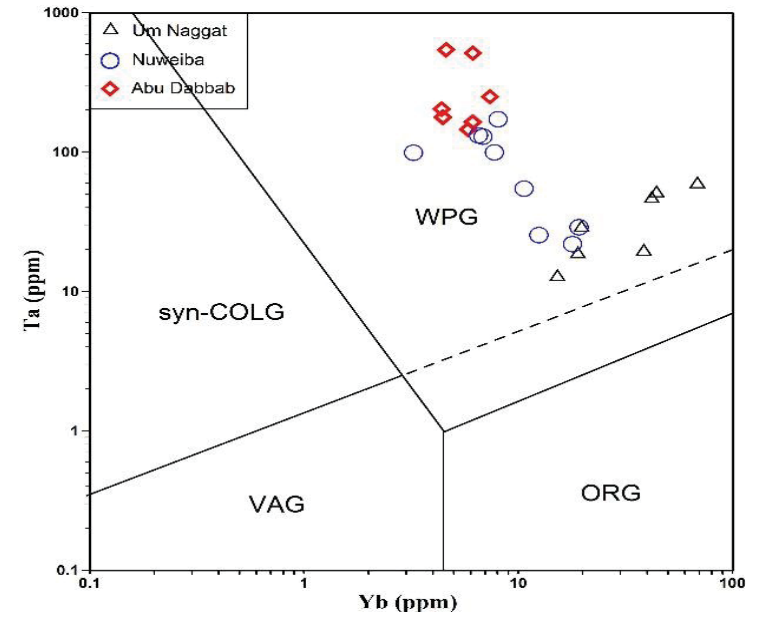

Fig. (17): Yb- Ta tectonic discrimination diagram after (Pearce et al., 1984).

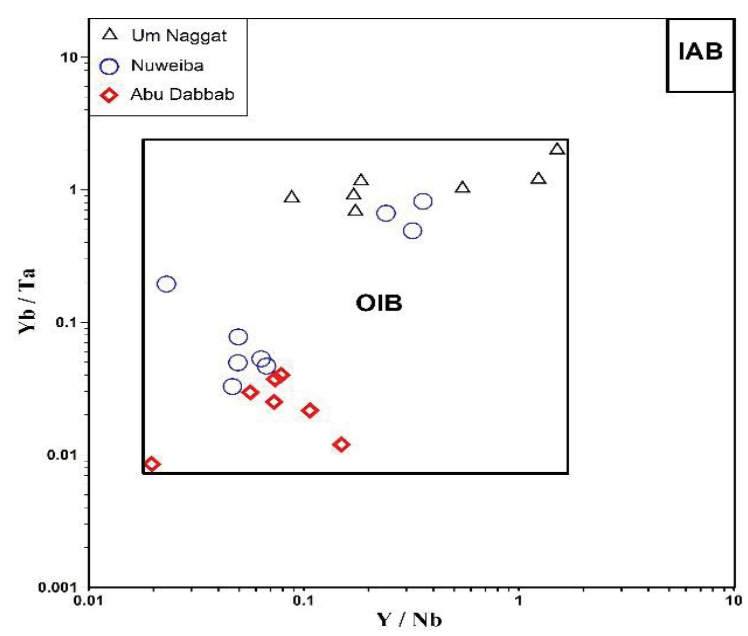

Fig. (19): (Y / Nb) vs (Yb / Ta) Diagram (Eby, 1990) showing the RMG of CED located in the OIB field.

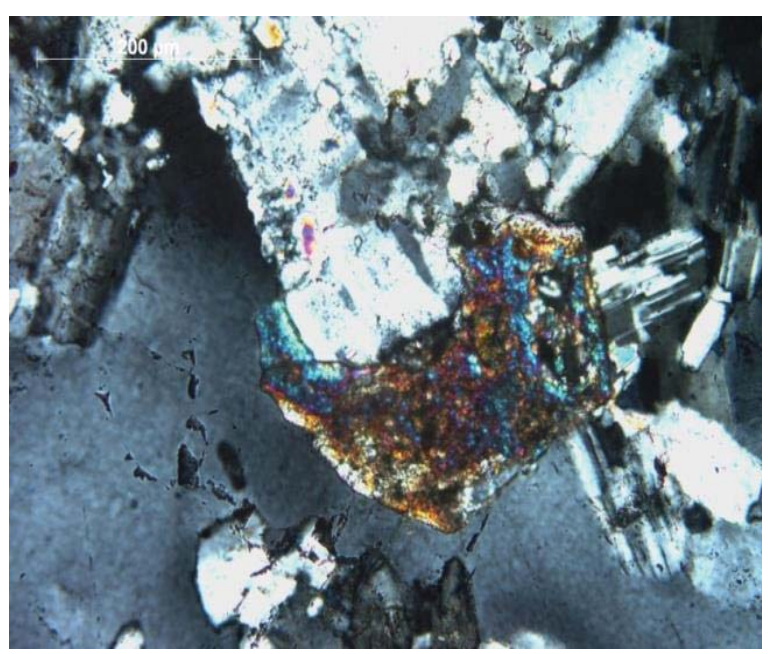

Fig. (21): Photograph showing primary albite corroded by quartz crystal, $C$. $N$. in Um Naggat area.

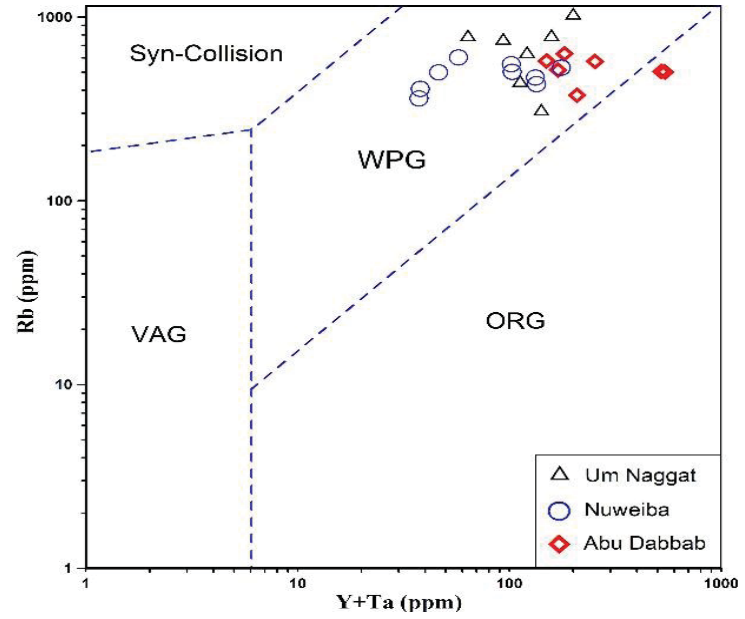

Fig. (18): Rb-(Y+Ta) tectonic discrimination diagram after (Pearce et al., 1984).

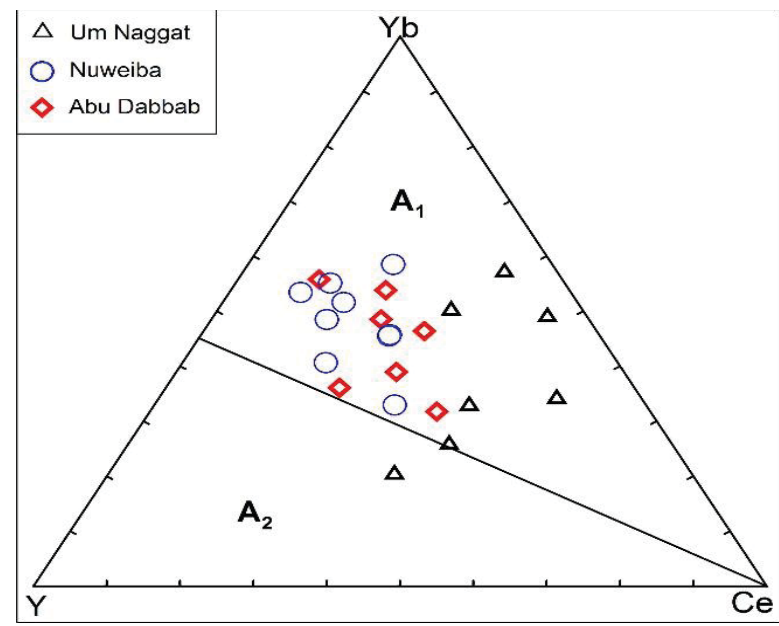

Fig. (20): Y-Ce-Ybternary diagram(Eby, 1992) showing the RMG of CED located in the A1 field.

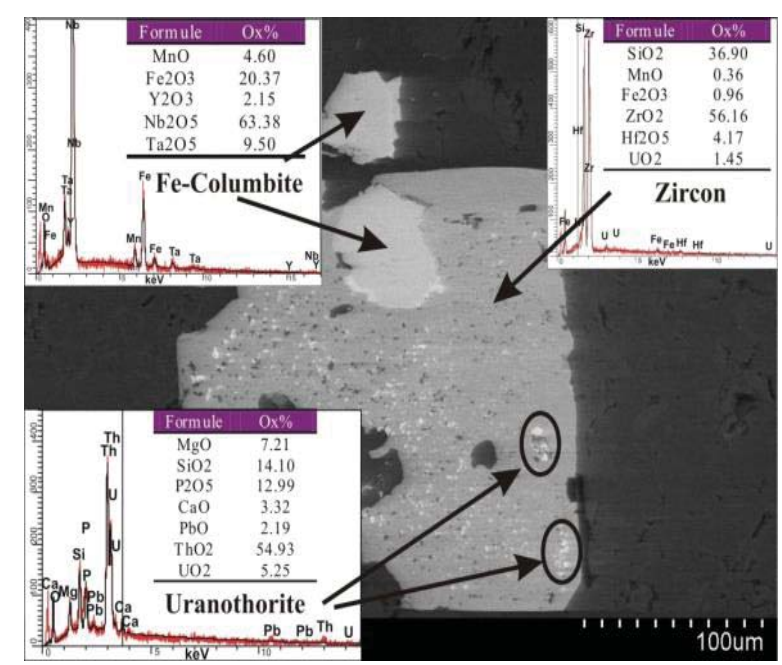

Fig. (22): SEM-BSE images for Fe-columbite and uranothorite minerals as inclusions in zircon in Um Naggat area. 


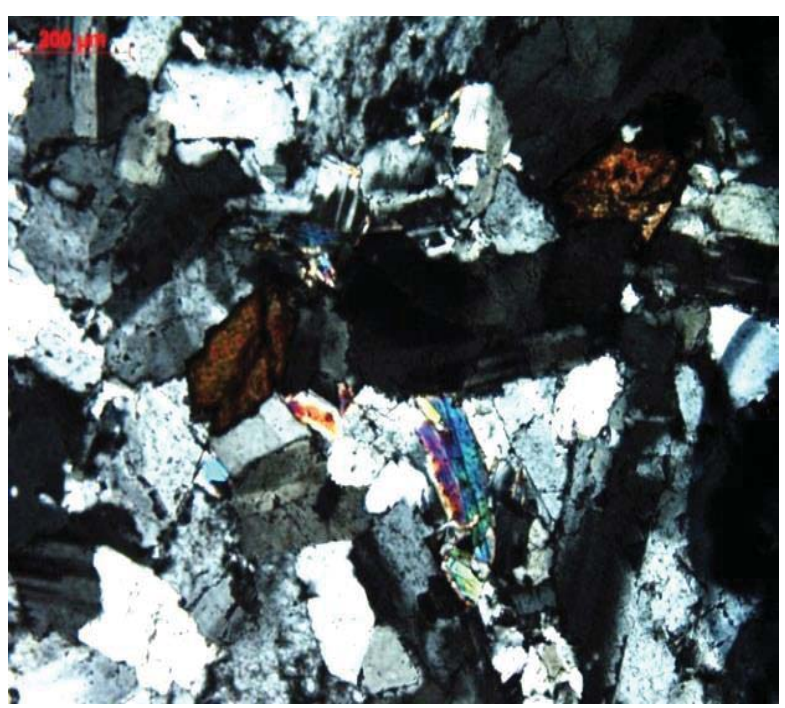

Fig. (23): Photograph showingsubhedralalbite crystal with anhedral crystals of quartz and muscovite. C. Nin Abu Dabab area

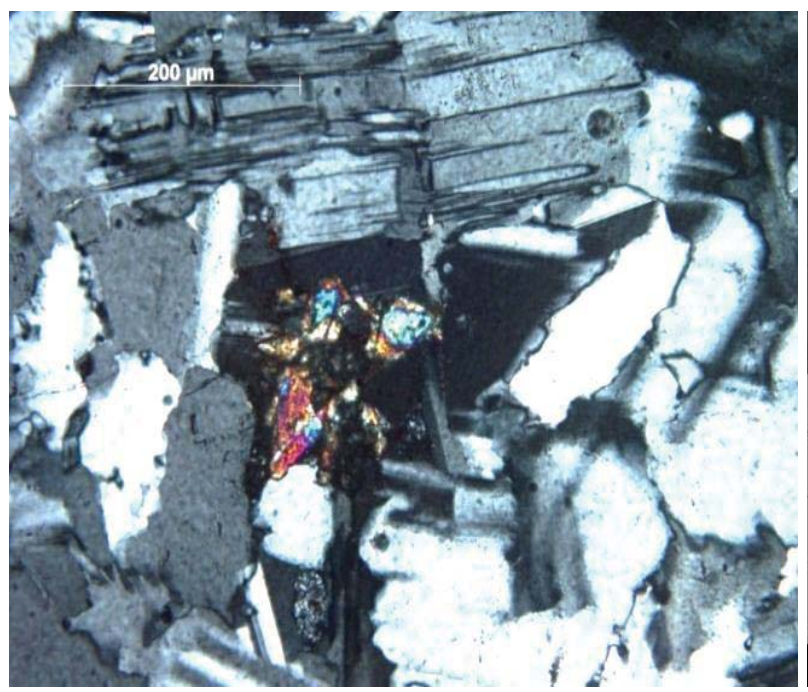

Fig. (25): Second albite phase $(0.2-1 \mathrm{~mm})$, subhedral to euhedral lath-shaped grains, Nweibi area

derived from an OIB-like source while granitoids that plot in the A2group were derived from the subcontinental lithosphere or lower crust. It should also be noted that A1-types invariably are associated with true anorogenic (within plate) settings.

\section{Origin of AlbiteRich Granites}

The argument about the origin of albite-rich granites is a point for many discussions and debates.Albite enrichment can be related to two completely distinct processes, either magmatic or metasomatic, according to the different occurrences. A metasomatic origin was proposed (e.g., Beus et al., 1962; Beus, 1968). Others and many

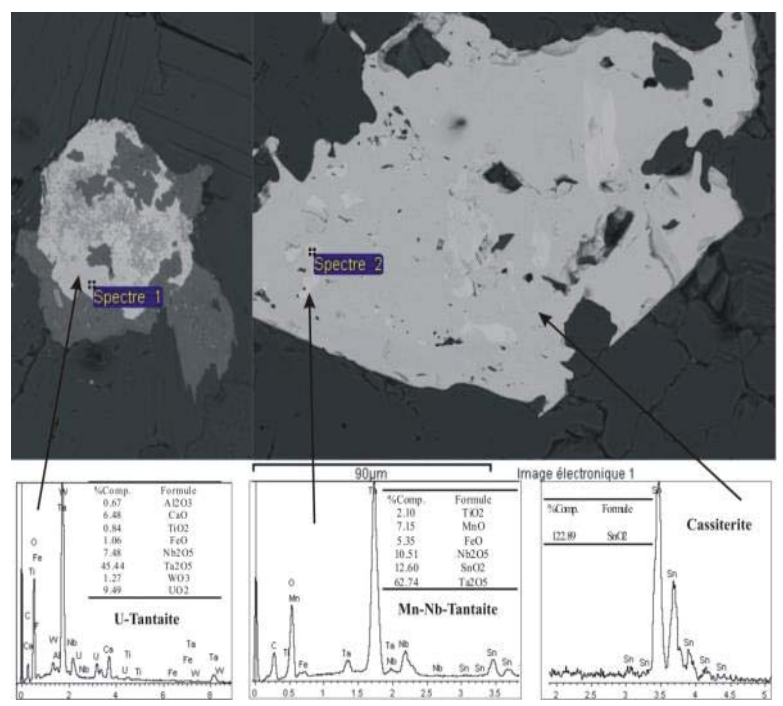

Fig. (24): SEM-BSE images for U-tantalite and NbMn-Tantalite minerals as inclusions in Cassiterite in Abu Dabab area

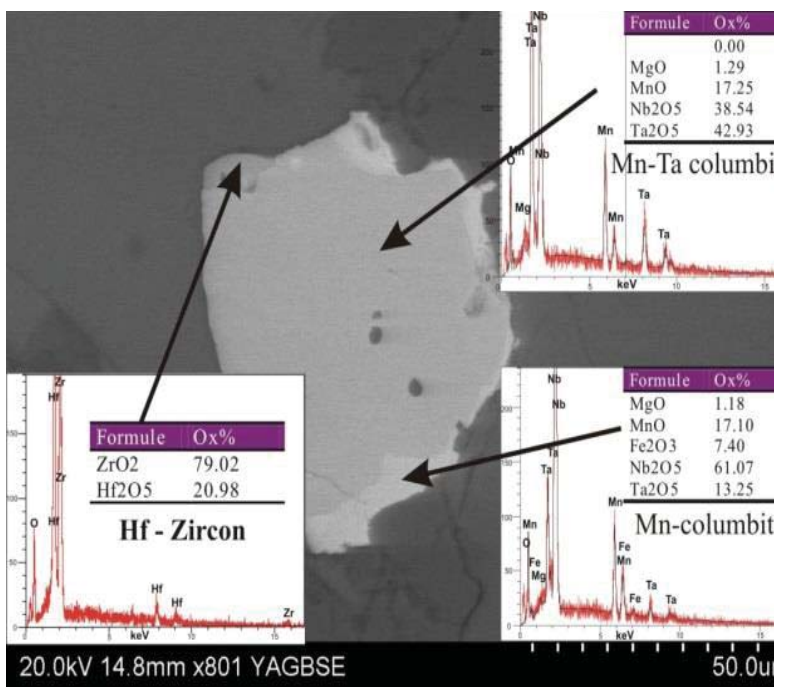

Fig. (26): SEM-BSE images for Mn-columbite and zircon minerals as inclusions in Tantalite, Nweibi area

recent workers considered the unusual compositional features of albite granites and rare-metal pegmatites to be magmatic (e.g. Černý, 1991).

Um Naggatalbite granite is found in the northern part of the Um Naggat granitic pluton. It is characterized by fine- to coarse-grains and white colour. Microscopically, it is characterized by fine- to coarse-grained crystals, with hypidomorphic (granitic) texture. Besides, porphyritic texture is found. Thealbite granite consists mainly of K- feldspars, quartz, plagioclase, biotite, and muscovite as well as zircon, fluorite, allanite and rutile that occur as accessory minerals.Plagioclase, in the Um Naggatalbite granite is one 
of the dominant minerals (An 8-10) and characterized by fine to medium grains and lamellar twinning. Deformed twinning and slight alteration to kaolinite are recorded. The albite is found in two generations. The first generation is magmatic albite, characterized by medium to coarse grains as porphyritic crystals corroded by quartz and K-feldespar (Fig.21). As a generality, the A2-type tend to be more frequently mineralized. In this case, the Um Naggatgranites have accessory zircon, columbite anduranothorite(Fig. 22). These granites are being prospected as potential U-Th ore deposits.

Abu Dababalbite granite is observed as leucocratic, holocrystalline and white to greyish white in color with black manganese oxides, which showdenderitic shape on fault planes. These granites are fine to medium in grain size and show hypidomorphic to porpheritic texture. Abu Dababalbite granite is composed mainly of plagioclase, quartz, potash feldspar, muscovite and iron oxides.Plagioclase is the most abundant mineral and occurs as euhedral to subhedral elongated crystals, medium to coarse grained and shows lamellar twining and in some cases deformed twinning due to deformational effects. This plagioclase is albite and oligoclase in composition. The albite is fine to medium grained, corroded by quartz which means that the albite crystals are formed magmatically. This albite is found as subhedral crystals with anhedral crystals of quartz and muscovite (Fig.23). Ta-Nbminerals (colombite-tantalite) up to $0.5 \mathrm{~mm}$ in size and cassiterite disseminated are recorded in albite granite of Abu Dabab area as bladed or prismatic euhedral to subhedral crystals (Fig. 24). These $\mathrm{Nb}-\mathrm{Ta}$ minerals are almost exclusively members of the columbite-tantalite series, mainly Sn-rich manganocolumbite and manganotantalite(Helba et al. 1997; Kuster 2009).

Nuweibialbite graniteshows some differences between its eastern and western parts in both mineral composition and texture. Albite and accessory minerals are more abundant in the eastern part than in the western parts of the study area, whereas K-feldspar, quartz and white mica show opposite behaviour. The texture of the eastern part tends to be porphyritic, with me- dium-grained quartz and K-feldspar phenocrysts embedded in a fine-grained, randomly oriented albite-rich groundmass. Meanwhile, the texture of the western part tends to be equigranular.Plagioclase is the most abundant mineral, mainly albite, in the eastern part where it reaches up to $61 \%$ by volume (average $50 \%$ ). Meanwhile, the western part of contains only about $33 \%$ by volume on the average. There are two phases of albite. The first phase is minute $(<0.15 \mathrm{~mm}$ in length), with euhedral laths included in quartz and $\mathrm{K}$-feldspar phenocrysts to form poikilitic texture (Fig. 25). The second phase is larger (0.2$1 \mathrm{~mm}$ ) with subhedral to euhedral lath-shaped grains in the groundmass. Mn-Columbite, Mncolumbo tantalite and Mn-tantalite are the main $\mathrm{Nb}$-Ta-bearing minerals in the studied Nuweibialbite granite samples. They occur as bladed or prismatic euhedral to subhedral crystals (Fig. 26). An important texture, developed locally at the granite contact, is the alignment of albite laths parallel to the contact. Flow-aligned albite is found in both the groundmass and in quartz phenocrysts, which represents a strong evidence for magmatic origin of the albite (Ali, 2003).

So, there are two different types of albite-rich granite: (i) Albite-rich granites resulting from albite enrichment occurring during magmatic crystallization as a consequence of increasing fluorine content in the melt during extreme fractionation (Abu Dabab and Nuweibi granites). (ii) Albitized granites which correspond to replacement of previous minerals by albite or new albite growth in the cavities left by other minerals which are dissolved during hydrothermal alteration of the granites (Um Naggat granites). Such alterationsare frequently associated with more or less extensive quartz leaching (episyenitization) and occur in limited zones of the granites controlled by tectonic structures.

\section{DISCUSSION}

\section{Implications for U Mineralization}

According to different mechanisms of albite enrichment; there is contrasting implications concerning uranium metallogenesis. The albitized granites may be associated with very important uranium mineralization, resulting from percolation of large volumes of hydrothermal 
fluids. Um Naggat is RMG although the albitization formed by metasomatism it derived from alkaline to peralkalinemagma and have high uranium abundance but hosted in highly refractory minerals. So, the cost of uranium extraction from such highly refractory minerals is very high. On the other hand, Abu Dabab and Nuweibi RMG were formed from highly fractionated melts and fluids where uranium can host by non-refractory minerals. Unfortunately, the absence of hydrothermal alterations and the small size of the granitic stock lead to decreasing the chance to form vein type U- mineralization which expected with such granites. Therefore, the uranium cannot be economic interest in the two areas with the present market conditions.

\section{The Role of Inherited Ductile Fabrics}

The principal geological structures, hosting many of the rare metal mineralization in Nweibi and Um Naggat granites include fractures, faults and shear zones that play the most important role in rare metal mineralization in the study area (Gaafar, 2014 and 2015). The continuous reactivation of these structures has had profound effect on the distribution of rare metal mineralization. Therefore, the delineated structures of the study area are likely to be potential hosts of rare metal ore mineralization. From the interpreted composite aeromagnetic structural map point of view (Fig. 14), three episodes of deformation D1-NE, D2-NNW and D3-NNE were observed.

Ali (2003; 2013)and Ali et al., (2008) analysed the ductile structures in the CED, Egypt. They foundtwo deformational episodes: a thrusting-folding episode that was associated with cratonization of the arc-interarc rocks (E1); and an upright folding episode (E2) following cratonization. The thrusting-folding episode is characterized by low-angle thrusting and tight to isoclinal folding that produced axial plane foliation and stretching lineations. The main ENE-WSW thrust faults, generated at this stage, define the contact between the dismembered ophiolitic slabs and the arc association volcano-sedimentary rocks. These thrust contacts and the (F1) axial plane foliations are folded about axes parallel to their strikes into upright asymmetrical (F2) folds. The estimated shortening direction for (E1) episode structure is NNW-SSE to NW-SE.
Syntectonic (older) granites were emplaced by imposing a regime of ductile deformation on the rocks of the envelope which provided up to $75 \%$ of the required space for the pluton (Cobbing, 2000). After cratonization, the second episode (E2) produced regional folds with major NW-SE axes that refolded the previous structures.

The age of (E1) episode must lie between the time of formation of the arc rock association and the intrusions of unshearedsyntectonic granites (intruded at about $612 \mathrm{Ma}$ ) (Sturchio et al., 1983). The syntectonic granites are considered to have been emplaced at the culmination of the low angle shearing tectonic event. The age of (E2) episode is bounded by the age of cratonization and the time of intrusion of late to posttectonic (younger) granites, i.e. 550-500 Ma. So, it can be detected in the molasse (Hammamat) sediments in the Eastern Desert of Egypt (AbdElmeguid, 1992; Ali, 2003; Abd-Elmeguid, et al., 2003).

The ENE-WSW and NNW-SSE to NW-SE trends can be considered as tectonic inheritants which control the granitic emplacement, multi injections and many alteration features during the different tectonic episodes. So, the inherited ductile fabrics can act as a mechanical discontinuities and deep-seated structures within the granitic plutons. Besides, the structural controls of the numerousmineralizations in the Eastern Desert of Egypt can be related to the interaction between inherited ductile fabrics and overprinting brittle structures (Ali et al., 2008).

It is clear that the central part of the study area, which is covered with older granites is characterized by a very low magnetic-intensity level on both the RTP and theregional maps (Figs. 13 and 15). These confirm that these acidic rocks extend to deep-depths up to more than 3 $\mathrm{km}$ and are mainly elongated in the East-West direction. It is noticed that the three rare metal zones; Um Naggat, in the northwestern part, Nuweiba in the southeastern part and Abu Dabab in the east part of the study area,possess low levels of magnetic intensity with an average of about 42250 nT (Fig. 13).

The serpentine rocks, that are located in the northeastern part of the study area represent the 
highest magnetic intensity, up to $42850 \mathrm{nT}$ (Fig. 13) and occupy a relatively large area that extend above the surrounding sedimentary rocks which indicates that it is outcropping of serpentine rocks. The metagabbros reflect a high level of the magnetic field intensity, and are distributed along different parts in the study area, with various forms, including circular-shapes in the eastern part, and elongated-shapes in the eastwest direction, that are located in the central and southern parts of the study area (Figs 13 and 15). Meanwhile, the metavolcanicsshow magnetic intensities range from low to high, indicating that, some of them are deep-seated and others are shallow, that mostly cover older granites or other acidic rocks (Figs 13 and 15).

The residual magnetic intensity map (Fig. 16), reflects the response of the surficial rocks. The sedimentary rocks located in the northeastern part of the study area is characterized by a low level magnetic field, compared to its high level on the regional-component magnetic map (Fig. 15). The serpentine and metagabbros are responsible for the highest magnetic anomalies on the residual magnetic map. Meanwhile, the three rare metal zones are generally characterized by their low magnetic intensity field (Fig. 16).

\section{Correlation between Inherited Ductile and Magnetic Fabrics}

The analysis and interpretation of magnetic structural trends in the study area reveal that the main structural trends are represented by the NW-SE direction as well as the NE-SW direction (Figs. 13, 14 and 16). The NW-SE direction represents the latest (youngest) trend, which affects all the rocks in the study area, while the NE-SW direction is considered to be older one that mostly attributed to metasedimentary rocks. This may be due to the metasedimentary rocks, which are characterized by ductile deformation and, thus, preserve much of the older structural trend (NESW), although they were also affected by latest structures (NW-SE direction), which sometimes supports the old one (Figs. 13, 14 and 16).

The correlation between the ductile and magnetic fabrics reveals structural similarities between both of them. On this basis, the ductile fabric may be considered as pre-existing deep- seated structures, influencing the trends and locations of brittle structures formed in later structural episodes. The brittle fabric was rejuvenated along the pre-existing fabric andexerted a strong control on later fluid activity and alteration features along the study area.

The tectonic fabrics, developed during ductile deformational events, are probably the main element of 'tectonic inheritance', frequently invoked to explain reactivation of old structures and parallelism of structures of succeeding deformations (either compressional or extensional) in continental domains. This may especially explain why continents break-up occurs parallel to ancient orogenic belts and may account for many characteristics of ocean basin development (Vauchez et al., 1998).

\section{CONCLUSIONS}

Um Naggatalbite granite is leucogranite derived from alkaline to peralkaline magma, associated with high abundances of $\mathrm{Zr}, \mathrm{Nb}, \mathrm{Th}, \mathrm{U}$, and $\mathrm{Y}$ with high $\mathrm{Nb} / \mathrm{Ta}$ and $\mathrm{Zr} / \mathrm{Hf}$ ratios. It was derived from both magmatic and metasomatic origins respectively. Meanwhile, Abu Dabab and Nuweibialbite granites are derived from peraluminous magma, associated with low $\mathrm{Nb} / \mathrm{Ta}$ and $\mathrm{Zr} / \mathrm{Hf}$ ratios, with no evidence to metasomatic process.

Rare metal granites of the CEDof Egypt are classified chemically into alkaline to peralkaline and peraluminous granites. They display the typical geochemical characteristics of A-type granites with high $\mathrm{SiO} 2, \mathrm{Na} 2 \mathrm{O}+\mathrm{K} 2 \mathrm{O}, \mathrm{Rb}, \mathrm{Zr}, \mathrm{Nb}$, Ta, $\mathrm{Sn}, \mathrm{Ga}$, and $\mathrm{Y}$, and low $\mathrm{CaO}, \mathrm{MgO}, \mathrm{Ba}$ and $\mathrm{Sr}$. The extremely high $\mathrm{Rb} / \mathrm{Sr}$ ratios combined with the obvious low $\mathrm{Sr}, \mathrm{Ba}, \mathrm{P}$, and Ti clearly indicate that these A-type granites were highly evolved and required advanced fractional crystallization in upper crustal conditions. Based on the characteristics of $\mathrm{U}, \mathrm{Th}, \mathrm{Nb}, \mathrm{Zr}, \mathrm{Zn}, \mathrm{Sn}$, and $\mathrm{Pb}$; it is suggested that these granites have the potential for rare metal and rare earth element mineralizations.

The main results, obtained from this study bring new elements allowing improvements of knowledge on the geological structures of the study area. Spatial analysis, helped detect mor- 
phological differences in the lineament patterns. The southern sector of the study area shows dense lineaments directed towards NW-SE trend. Meanwhile, its northern and central sectors indicate dense of lineaments directed towards NESW trend. Accordingly, the studied terrain can be divided into two tectonic sectors. Comparison of the results with the geoscientific data (structural and lithological), confirms both morphological difference and tectonical subdivision into two tectonic sectors. Moreover,it helped to identify the structural boundary separating both of them at depth assigned to major normal faults in the center. This geophysical study suggests that the modelled structures of crust are situated on the flanks of major faults in the basement: they are a product of an active continental collision. Airborne magnetic datasets were used to delineate lithology, structure and alteration zones in the study area. The main purpose of interpretation of the geophysical maps was to identify individual lithology and delineate structures, which control rare-metal mineralization in the study area. Low magnetic susceptible areas, which might have resulted from rock alterations or possible mineral deposits are delineated as potential targets for ore deposits.

The aeromagnetic data identified high magnetic contrasts between rock bodies situatedalong the contact zones. They are interpreted as potential pathways for fluid migration and mineralization. In order to predict favourable locations for possible blind ore deposits in the study area, both structural and alteration patterns were taken into consideration. High structural connectivity and areas of intensive alterations reflected as low magnetic anomalous zones, were considered. They are particularly marked by faults, fault intersections, fractures and shear zones. The proposed relationship shows that the hydrothermal system is structurally controlled and not limited to any specific lithology or host rock.

The aeromagnetic structural lineaments suggest that the study area was subjected to an important regional field stress. The interpreted magnetic structural map, obtained for the study area is dissected by many faults, which have different directions indicating a complex tectonic history and several events of deformation. Major structures in the basement trend in ENE -WSW to NE-SW direction. The predominant NW-SE structural trend affecting the study area, extends from its southwest to its extreme northeastern part.

Consequently,magmatism of rare metal granites of the CED of Egypt, are related to anorogenic, within plate, A-type, subvolcanic settings and emplaced in extensional tectonic regime along inherited ductile fabrics.

\section{REFERENCES}

Abdalla, H. M., Helba, H. A. and Mohamed, F. H., 1998: Chemistry of columbite-tantalite minerals in rare metal granitoids, Eastern Desert, Egypt. Mineral. Mag. V. 62, N. 6, pp. 821-836.

Abd-Elmeguid, A. A., Ammar, S. E, Ibrahim, T. M. M., Ali,Kh. G., Shahin, H. A., Omar, S. A, Gaafar, I. M., Masoud, S. M., Khamis, A. A., Haridy, M. H., Kamel, A. I., 2003: Uranium potential of Eastern Desert granites, Egypt. Internal Report, (Unpublished) Nuclear Materials Authority, Egypt.

Abd-Elrahman, A.M., and El-Kibbi, M.M., 2001: Anorogenicmagmatism: chemical evolution of the Mount El-Sibai A-type complex (Egypt), and implications for the origin of Within- Plate Felsic magmas. Geological Magazine, V. 138, pp. 67-85.

Aero Service, 1984: Final operational report of airborne magnetic/radiation survey in the Eastern Desert, Egypt, Aero Service Division, Houston, Texas, V. 6.

Ali, Kh. G., 2013: The role of inherited ductile fabrics in developing the most favourable structures hosting uranium within the fertile granitic plutons of the Eastern Desert, Egypt. Annals Geol. Surv. Egypt.

Ali, Kh. G., 2003: Geology and radioactivity of Naba-Nuweibi area, Central Eastern Desertm, Egypt. Unpub. Ph. D. Thesis, Ain Shams Univ., Cairo, Egypt, 194 p.

Ali, Kh. G., Gaafar, I. M., and Ibrahim, T. M., 2008: Structural control and geophysical signature of KabAmiriepisyenitized muscovite granite and associated uranium showings, Central Eastern Desert, Egypt. Annals Geol. Surv. Egypt. V.XXX, pp. 21-41.

Batchelor, R. A., and Bowden, P., 1985: Petrogenetic interpretation of granitoid rock series using multicationic parameter Chemical Geology, V. 48, pp. 43-55.

Beus, A. A., Severov, V. A., Sitnin, A. A., and Subbotin, K. D., 1962: Albitized and greisenized granites (apogranites): Moscow, AkademiiaNauk SSSR, 196 p. (in Russian).

Beus, A. A.,1968: Geochemical exploration for endogenic deposits of rare elements on the example of tantalum. 
Nedra, Muscow, Engl. Transl. GSE Libr, Ottawa, Canada.

Cobbing, J., 2000: The geology and mapping of granite batholiths. Springer-Verlag Berlin Heidelberg, 141 p.

Cuney, M., Marignac C., and Weisbrod, A., 1992: The beauvoirtopazlepidolite-albitegrantie (Massif Central, France) disseminated magmatic Sn-Li-Ta-Nb-Be mineralization. Econ Geol.,V. 87, pp.1766-1794.

Debon, F. and Le Fort, P., 1983: Chemical-mineralogical classification of plutonic rocks and associations-Example from southern Asia belts. In: XuKeqin and TuGuangchi (eds.), Geology of Granites and their MetallogeneticRelations. Sc. Press, Beijing, pp. 293-311 (Equally in Chinese).

Dobrin, M.B., and Savit, C.H., 1988: Introduction to geophysical prospecting (4th ed.), New York, McGrawHill, 867 pp.

Eby, G.N., 1990: The A-type granitoids: A review of their occurrences, chemical characteristics and speculations on their petrogenesis. Lithos, V. 26, pp. 115-134.

Eby, G.N., 1992: Chemical subdivision of the A-type granitoids: petrogenetic and tectonic implications. Geology V. 20, pp. 641-644.

Egyptian Geological Survey and Mining Authority (EGSMA), 1992: Geologic map of Wadi Al-Barramiyah Quadrangle, Egypt.

Fetherston, J. M., 2004: Tantalum in Western Australia. WA Geological Survey, Mineral Resources Bulletin,V. 22, pp. 162.

Frank, M., Torsten, G., Hans-Eike, G., Maria S., Friedhelm, H., Thomas O., Axel, G., and Stijn, D., 2015: Tantalum-(niobium-tin) mineralisation in African pegmatites and rare metal granites: Constraints from $\mathrm{Ta}-\mathrm{Nb}$ oxide mineralogy, geochemistry and $\mathrm{U}-\mathrm{Pb}$ geochronology. Ore Geology Reviews, V. 64, pp. 667-719.

Gaafar I. M., 2014: Geophysical Mapping, Geochemical Evidence and Mineralogy for Nuweibi Rare Metal Albite Granite, Eastern Desert, Egypt. Open Journal of Geology, V. 4, pp. 108-136.

Gaafar I. M., 2015: Integration of geophysical and geological data for delimitation of mineralized zones in Um Naggat area, Central Eastern Desert, Egypt.In Press.

Gippsland Ltd., 2007: Annual Report, Gippsland Limited, Perth, Western Australia. http://www.gippslandltd. com.

Govindaraju, K., Mevelle, G., and Chouard, C., 1976: Automated optical emission specto-chemical bulk analyses of silicate rocks with microwave plasma excita- tion. Anal. Chem.,V. 48: pp. 1325-1331.

Greiling, R.O., Kröner, A., El Ramly M.F., Rashwan, A.A., 1988: Structural relationships between the southern and central parts of the Eastern Desert of Egypt: details of a fold and thrust belt. In: El-Gaby, S., Greiling, R.O. The Pan-African belt of Northeast Africa and adjacent areas. Germany, Vieweg publisher, Wiesbaden-Braunschweig, pp.121-146.

Helba, H., Trumbull, R. B., Morteani, G. and Khalil, S. O., 1997: Geochemical and petrographic studies of Ta mineralization in the Nuweibialbite granite complex, Eastern Desert, Egypt. MineraliumDeposita, V. 32, pp. 164-179.

Jeng, Y., Lee, Y.L., Chen, C.Y. and Lin, M.J., 2003: Integrated signal enhancements in magnetic investigation in archaeology. Journal of Applied Geophysics, V. 53, pp. 31-48.

London D., 1987: Experimental phase equilibria in the system LiAlSiO4-SiO2-H2O: a petrogenetic grid for lithium-rich pegmatites. American Mineralogist. V. 69, pp. 995-1004.

Maniar, P. D., and Piccoli, P. M., 1989: Tectonic discrimination of granitoids. Geological Society of Am. Bull., V. 101, pp. 63 5-643.

Murphy, B. S., 2007: Airborne geophysics and the Indian scenario. J. Ind. Geophysics Union, V. 11,No. 1, pp. $1-28$.

Pearce, J. A., Harris, N. B. W. and Tindle, G., 1984: Trace elements discrimination diagram for the tectonic interpretation of granitic rocks. Jour. Petrol., V. 25, pp. 956-983.

Petro, W.L.T., Vogel, T.A., and Willband, J.T., 1979: Major element chemistry of plutonic rocks suites from compressional and extensional plate boundaries. Chemical Geology, V. 20, pp. 217-235.

Plumlee, G., Smith, K. S., Ficklin, W., and Briggs, P. H., 1992: Geological and geochemical controls on the composition of mine drainages and natural drainages in mineralized areas. Proceedings, 7th International Water-Rock Interaction Conference; pp. 419-422. Park City, Utah, USA.

Reid, A.B., Allsop, J.M., Granser, H.,Millett, A.J. and Somerton, I.W., 1990: Magnetic interpretation in three dimensions using Euler deconvolution. Geophysics, V. 55, pp. 80-90.

Renno, A. D., Schmidt, W. and Shalaby, I. M., 1993: Rare-metal province Central Eastern Desert, Egypt-II. A-type granites of Abu Dabab, Igla and Nuweibi. In: Thorweihe\&Schandelmeier (eds.), Geoscientific Research in Northeast Africa, Balkema, Rotterdam, ISBN, pp. $483-488$.

Rickwood, P. C., 1989: Boundary lines within petrologic diagrams which use oxides of major and minor elements. Lithos, V. 22, pp. 247-263. 
Roest, W. R., and Pilkington, M.,1993: Identifying remanent magnetization effects on magnetic data. Geophysics, V. 58, pp.653-659.

Sabet, A. H., Tsogoev, V. B., Shibanin, S. P., El-Kadi, M. B., and Awad, S., 1976: The placer deposits of Igla, Abu Dabab and Nuweibi, Ann. Geol. Surv. Egypt, V. 6, pp. 169-180.

Silva, A. M., Pires, A. C., Mc-Cafferty A., Moraes, R., and Xia, H., 2003: Application of airborne geophysical data to mineral exploration in the uneven exposed terrains of the Rio Das Velhas greenstone belt. RevistaBrasileira de Geociências, V. 33, No. 2, pp.17-28.

Telford, W.M., Geldard, L.P.,Sherriff, R.E., and Keys, D.A., 1990: Applied geophysics. 2nd edition, Cambridge University Press, Cambridge, Great Britain (GB), $860 \mathrm{p}$.
Thompson, D.T., 1982: EULDPH: A new technique for making computer-assisted depth estimates from magnetic data. Geophysics, V. 47, pp. 31-37.

Vasanthi, A., Sharma, K. K., and Mallick, K. (2006): On new standards for reducing gravity data: The North American gravity database, Geophysics, V. 71, pp. 31-32.

Vauchez, A., Tommasi, A., and Barruol, G. (1998) Rheological heterogeneity, mechanical anisotropy, and tectonics of the continental lithosphere, Tectonophysics, V. 296, pp. 61-86.

Whalen, J. B., Currie, K. L., and Chappell, B.W., 1987: Atype granites: geochemical characteristics, discrimination and petrogenesis. Contrib. Min. Petrol., V. 95, pp. 407-419.

\section{البصمة الجيوفيزيائية والجيوكيميائية للجرانيت الغنى بالمعادن النادرة، وسط الصحراء الثرقية، مصر: تأثير البيئة

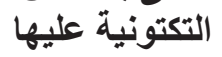

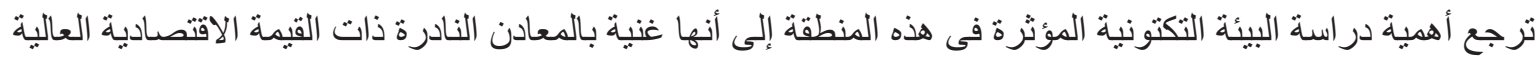

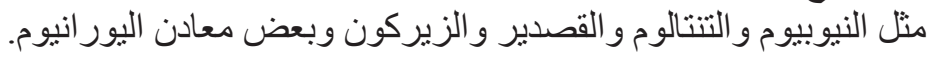

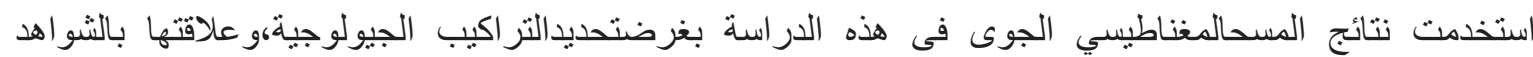

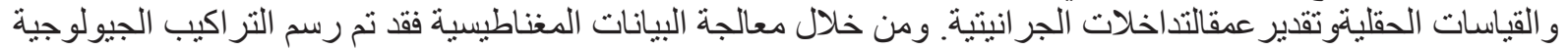
وتحديد أعماقها من خر ائط الثندة المغناطيسية الكلية المحولة الىىالقطبالثماليوخريطة المشتقة الر أسية الأولية وخريطة حساب الأعماق 3D-Euler Deconvolution

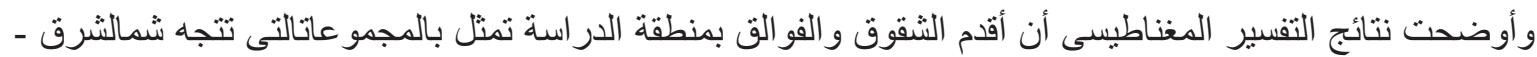

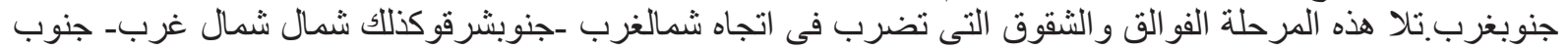

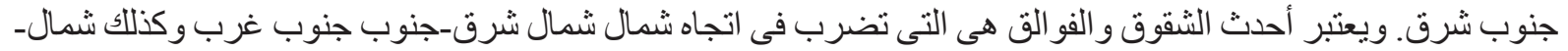

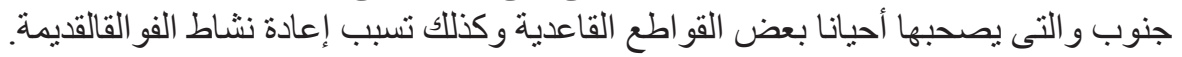

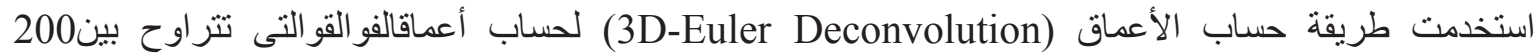

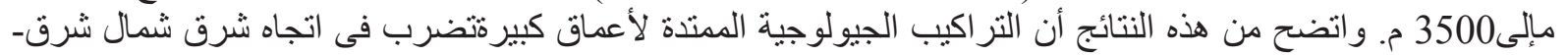

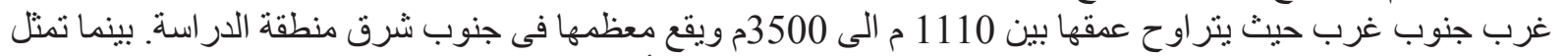

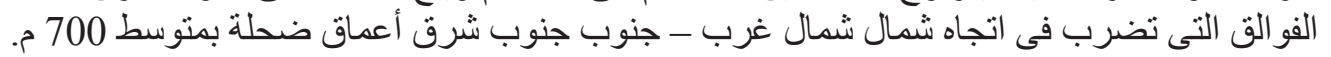

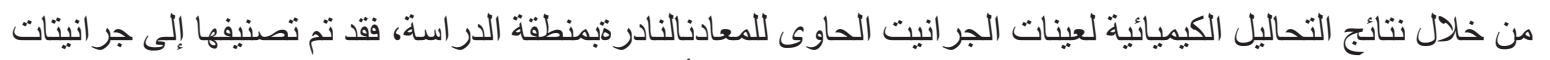

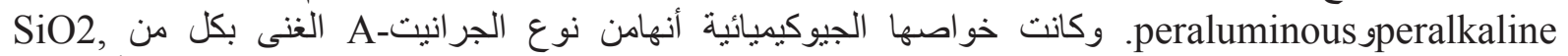
CaO, MgO, Ba and Sr Na2O+K2O, Rb, Zr, Nb, Ta, Sn, and Y

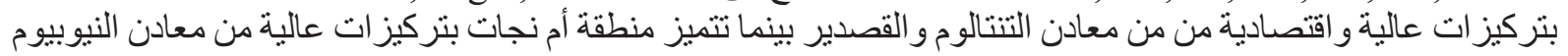

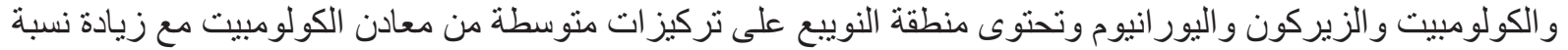
التنتالوم الى النيو بيوم وتحتوى على على بعض معادن اليور انيوم ونيو الزيركون. 